\title{
Kupała and Kołas Manuscripts and Marginalia in the Francis Skaryna Library, London
}

BY

ARNOLD MCMILLIN

Amongst the rich collection of manuscripts and documents held by thi Francis Skaryna Library ${ }^{1}$ are a number of important MSS and other mater ials relating to Byelorussia's two greatest writers, Janka Kupała and Jakul Kołas. Having come to the Library as a donation in 1975, they not onl: represent great historical interest and value, but also throw new light or the textual history of some works, give an insight into the poets' creativ' processes, and, in the case of Kupała's Chaưrusnikam, add a hithert unknown work to the poet's canon.

The Kupała collection consists of:

1. The original MS of Kurhan.

2. Neat unsigned MS copies of Rodnaje stova and Pamiaci Vincukı Marcinkieviča.

3. A signed and dated MS of Chaŭruśnikam.

4. A shapirograph copy made by Epimach-Sypiła of Piered visial niej in 1908.

5. Seven pages of proofs of Maładaja Bietarus, vol.1, pt 3, with cor rections and instructions to the printers from Kupała.

The Kołas collection consists of:

1. A neat signed MS of the Introduction to Symon-muzyka.

2. A neat corrected unsigned MS of eleven items from Druhoj čytańnie dla dziaciej biełarusaù.

3. An unsigned MS of Dola batrački with miscellaneous othe material in the margins and on the verso.

4. A dated but unsigned MS of Pole with miscellaneous roug] material on the verso.

5. A rough draft for Vodhulle with miscellaneous rough material o: the verso.

6. A signed and dated verse Panskaj Polščy, parts of whic. appeared in print as Polskim katam, with miscellaneous roug material on the verso, some of which is also related to Polskir katam.

7. A neat signed MS of Mova Łyńkova pa ramanu ' $\mathrm{Na}$ čyrvonyc ladach'.

8. A signed undated publicist MS, Padumajcie ab dzieciach!, with miscellaneous rough material on the verso of sheets 2 and 3

9. A travel document dated 4 April 1921.

10. An unsigned MS of an unfinished poem to Anton Łuckievič.

I

The most important item in the collection is undoubtedly the origin: manuscript of Kurhan, with dedication to S. Pałujan, signed Ja. Kupała. and dated 23.V.1910. The first of Kupała's three major narrative poems c 
this period, Kurhan was sent by the author, at that time living in St Petersburg, to the editorial offices of Naša niva in Vilna where it was subjected to a number of editorial amendments, probably by Anton Łuckievič, made in red ink, but with others, apparently later, in pencil, before being published in $1912(\mathrm{Nn}, 21$ June $1912, \mathrm{pp} .1-3) .^{3}$ It consists of seven sheets of unlined paper $22 \times 36 \mathrm{~cm}$ (figs $1-7$ ).

The notes on the variant readings and corrections of this poem in the latest collected edition of Kupała's works ${ }^{4}$ are not comprehensive; indeed, they are even inaccurate when referring to the first five stanzas which are illustrated in this edition, copied from the journal Cyrvonaja Bietaruś, 1932, no. 18. Apart from the mistake of describing the first stanzas of the poem as 'the first page' when the latter contained seven stanzas, there is, to take but one example, a plain mis-reading of 'Kamni, zielle...' for 'Pałynzielle...' in the corrected sixth line. ${ }^{5}$ It is to be hoped that reproduction of the manuscript in toto will facilitate the preparation of a much more reliable academic edition of the poem in future, taking into account both the variants found in the autograph and its amendments. The great majority of cases where the manuscript differs from the $Z t$ version are grammatical, as, for instance, in 1.129 where kości appears for kościej, or in 1.32 pakryjomu for pakryjoma, or in 1.62 zavodzie for zavodzić. In some such cases the MS form is also found in $N n$, in others not. In the case of ston for stohn, which should properly be regarded as removal of a russicism, $N n$ has ston in 1.55 , but stohn in ll. 139-40 - a reminder of the still relatively fiuid state of the Byelorussian literary language in the second decade of this century. Other still clearer cases of the substitution of a Byelorussian word for a russicism, like vodklik for echa (1.75) or pačynać for načynać (1.92) are usually found in $N n$, but a few including, for example, bačyš for vidziš (1. 105) or stary for staryk (1.151), were not made in either $N n$ or the Ślacham žyćcia (hereafter $\breve{S z}$ ) edition of 1923; indeed, stary does not even appear in the 1936 twovolume edition of Kupała's works, ${ }^{6}$ giving cause for speculation as to its origins. Finally, it may be mentioned that the majority of the red 'corrections' on the manuscript concern punctuation; sometimes this has been followed by later editiors, sometimes not. In 1.184, for instance, the manuscript is punctuated thus: ' $Z$ kurhana, jak śnieh bieły, vychodzie', as in $N n$. The $\check{S} \check{z}$ edition and $Z t$, on the other hand, have the second comma after 'śnieh'.

The neat unsigned manuscripts of Rodnaje stova and Pamiaci Vincuka Marcinkieviča are on 4 (joined) yellowing sides of faintly lined watermarked machine-made paper $21.6 \times 27.5 \mathrm{~cm}$, apparently taken from an exercise book. The watermark, which is of the Neva Paper Mills, occurs four times and indicates that the paper was made no earlier than $1906 .^{7}$ Both poems were published in Naša niva in 1910: Rodnaje słova in no. 51, Pamiaci Vincuka Marcinkieviča in no. 48. The MS versions, undoubtedly in Kupała's hand (see fig. 8), give the impression of an early clean copy. Differences between this version and the printed versions in $N n$ and $Z t$ are relatively few and most came in before publication in $N n$. In Rodnaje stova they range from the addition of asterisks after every two stanzas to small adjustments of spelling, an exception being the substitution of staroncy for MS, $N n$, and $\zeta \check{z}$ stranicy. The appearance of śmiajecca as the last word of 1.36 of this poem appears to be a simple slip of the pen, since the previous line also ends in this way. The variants which cannot be seen in fig. 8 are as follows:

Rodnaje stova

1.30 Jak u dumkach sonnych [?] tiabie hadavali

1.36 Heta abo viecier, što ù płatach śmiajecca 


\subsection{Biełarus upiša na staroncy čystaj}

Pamiaci Vincuka Marcinkieviča

1.9 S samich nas i z hutarki našaj

1.37 Złaǔniǔsia tak składna nastroić

1.47 Žyć budzie tak kodony [?], moj bratka.

Finally, it may be mentioned that the dedication of Rodnaje stova in Naša niva 'To the editors, workers, readers, and supporters of Naša niva' in the MS version omits mention of the workers ('supracoǔnikam'). Did Kupała simply forget when making a clean copy, or did the broader dedication arise only when the poem was in the hands of the dedicatees themselves?

Of major importance is the signed and dated MS of a hitherto unpublished poem Chaǔruśnikam (fig.9). In fairly faint blue ink on yellowish unlined paper $20 \times 35.5 \mathrm{~cm}$, it has a large grease mark in the bottom lefthand corner. The subject is one that Kupała treated often in his literary and publicist works, namely the unwillingness of Poles and Russians alike (here represented by Gazeta codzienna and Vilenskij vestnik, respectively) ${ }^{8}$ to take into account the desire of Byelorussians for independence, seeking rather to divide the country betweeen themselves. In drama we have the play Tutejšyja (1922, not republished in Zt), and his ironical publicist article of 1914 'A ǔsio ž taki my žyviom!.... . One strange aspect of the MS is the date, $19 / \mathrm{X}-1913$, where the ' 1 ' of ' 13 ' is very thick, looking as if it might obliterate another number, such as ' 2 '.

The shapirograph copy of Kupała's Piered visialniej (fig.10) is also of interest. It was made in 1908 in the offices of Naša niva by Branisłaŭ Epimach-Sypiła and circulated amongst his friends, being first published only in 1929 in Potymia with, according to Kupała, some small corrections. On a sheet of yellowing paper $21.7 \times 35 \mathrm{~cm}$ it is in Epimach-Šypiła's handwriting reproduced in mauve ink, with a pencilled ' 49 ' in the top lefthand corner, and in the top right-hand corner a circular device denoting clean paper ('čistaja bumaga') with the figure 6 in the centre.

Of more marginal interest are some fragments of proofs, corrected by Janka Kupała, from Maładaja Biełaruś (series 1, volume (š̌ytak) 3), pp.1723. In the top left-hand margin Kupała has written 'Correct, arrange the numeration of pages as indicated, make the proofs in a more decent way, and send again for checking', adding the date 25.4.1913. The pages are renumbered from 1-8 and 17-23 in bold blue pencil with a request from Kupała to close up ('perenesti rjadom') the blank p.6. They comprise three poems by Kanstancyja Bujła and a story (one of three) by Hałubok. The Bujła poems are 'Dzień skanaǔ za haroj, a nad sonnaj ziamloj...', 16 4-line stanzas, pp. 1-3 (17-19) (reproduced in Dvarčanin), ${ }^{10}$ Ruta, pp.3-4 (19-20), and Adna p.5 (21); ${ }^{11}$ there is an apparent mistake in Kupała's correction of the first line of the latter poem, 'Adna iznoǔ adna, jak kołas toj u poli', where he suggests placing a comma after 'iznoǔ'. Dvarčanin places the comma after 'adna', as also seemed more natural to the editor of the first edition of Bujła's Kurhannaja kvietka in 1914. The final work in these proofs is Hałubok's story Apošniaje spatkańnie. It is noteworthy that Maładaja Biełar-

$u s$ was at that time prepared to use Latin script for Bujła and Cyrillic for Hałubok. ${ }^{12}$

II

The Library's collection of materials relating to the life and work of Jakub Kołas is still more varied. Pride of place is undoubtedly taken by a 
signed MS of the Introduction to Symon-muzyka on a scrap of squared paper $12.5 \times 22.5 \mathrm{~cm}$ (fig. 11). The differences between this autograph and $Z t$ which occur in ll.5, 8, 9, 13, 19 are mostly insignificant points of punctuation, although 1.9 and, especially, 1.19 show signs of the poet's search for the ideal word. This early part of Kolas's masterpiece was written in 1911, although many years were to pass before publication of the poem as a whole.

The neat corrected MS version of eleven items from Kołas's reader for children Druhoje čytańnie dla dziaciej bietarusaŭ ${ }^{13}$ consists of 14 numbered sheets of foolscap written on one side only in black ink, with corrections in the same hand. In the top left-hand corner of the first page (fig. 12), the figure 5.5 and a square are in red. The date at the top, 1906-7, is underlined and seems to have been added later; it appears again, scrawled at the top of p.7 with Kołas's initials. ${ }^{14}$ The orthography in these excerpts is, perhaps not surprisingly, highly unorganized, and the hand differs considerably from Kołas's mature writing. However, the corrections are in his more familiar rounded script. It seems likely that he used this neatly sloping hand in order to present his material to the printers as clearly as possible. Comparison with other examples of his early handwriting leave no doubt that the writing is indeed his. ${ }^{5}$

The items, all of which (and many more) are in $Z t$, apart from the Zadačka (Questions) appended to the prose sketch Viasna, comprise:

Viasna and Zadačka

Prylot ptušak

Pieśnia tastaǔki

Viasna ('Idzie viasna ǔžo, dziakuj bohu')

Viasna na Paleśsi

Nioman

Muraški

Dub $i$ čarocina

Eastaǔki.

Changes to the text (for example the replacement of 'słaǔny' by 'piekny' as the second word of Viasna) were incorporated in the printed version of the text ${ }^{16}$ and $Z t$. The orthography consistently uses $\breve{u} o$ for $e$ (with the force of $\ddot{e})$ and $\ddot{e}$, in which connection it may also be noted that $Z t$ refers to a MS in Latin script preserved in the Jakub Kołas Museum. ${ }^{17}$ There are a few variant readings. In Pieśnia tastaǔki the last line of the second stanza was 'Budu žyta źbierahać', then became 'Budu bydła pilnavać' (this is the version in $Z t$ ), but was changed back by Kołas to 'Budu žyta pilnavać'. Near the end of Prylot ptušak there is a footnote explanation (not retained in $Z t$ ) of 'sytaǔki' as 'pliski', and 'knihi' as 'knihaŭki-čajki', and in Viasna na Paleśsi 'čarotam' is explained as 'traśnikom' (also omitted in Zt). In Dub i čarocina 'Ustupiła čarocina $z$ dubam $u$ razhavor' is crossed out and replaced by 'Zavieta čarocina $z$ dubam havor'; $Z t$, on the other hand, has 'Zaviała carocina $\mathrm{z}$ dubam hutarku'.

Three similar scraps of squared paper $12 \times 22.5 \mathrm{~cm}$. contain interesting material for analysis of Kołas's creative methods. The first is a copy of Dola batrački with marginal verse jottings (fig. 13), with on the reverse (fig. 14) an apparently inconclusive attempt to write another poem, trying out various rhymes and words. Dola batrački was first published in Naša niva (22 May 1908), and this MS sometimes coincides with $N n$, sometimes with $Z t$, when they differ; compare, for instance, 11.23 and 24 with these printed sources. It should also be mentioned that both the $N n$ and $Z t$ versions are 
longer (though not of the same length). The second poem, Pole, is dated $1916,{ }^{18}$ like Dola batrački in black ink, but written out more neatly. Of the variant readings (compared with $Z t$ ) below only 1.9 appears to have more than merely formal significance:

1. 9 'Voś i trecie daǔ boh leta'

1.12 'Jak ranej, ich hałasoŭ'

1.13 'Dzie-ž vy dzielisia, sialanie'

1.19 'Chto-ž mnie skaža za dola' where ‘Chto-ž mnie skaža...' replaces 'I nie kažuć...'.

On the reverse of this sheet (fig. 15) is a seemingly disorganized set of lines, each beginning with a capital, but many of them unrhymed and with numerous deletions. In addition to an elementary calculation in the marn is what appears to be a riddle, written vertically. The third poem is a rough draft of Vodhulle, written fairly neatly but with corrections (fig. 16). On the reverse (fig. 17) is a rather scrappy collection of odd lines, phrases, and quotations. All three of these fragments and drafts offer an interesting insight into Kołas's creative methods.

The same may be said of Panskaj Polščy, a signed and dated MS on a scrap of unlined yellowed paper $12 \times 22.5 \mathrm{~cm}$. The MS consists of 74 -line stanzas dated 18.12.1931 which, although never printed separately, are largely incorporated into Polskim katam (hereafter $P k$ ), which, according to $Z t$ (II, p.487), is also dated 18.12.1931; Polskim katam was in any event published remarkably soon after this date: in Savieckaja Biełaruś, 1931, no. 293 (22 December). For a poem that was never published as such, the copy of Panskaj Polščy (fig. 18) is remarkably neat and, with its signature and date, unlike a draft in any sense. The MS version is identical with $P k$ in $11.1-6,8$, $10-12$, but 11.7 and 9 are changed somewhat; stanza 4 of the MS corresponds to ll.29-32 (stanza 8 - but $Z t$ does not divide the poem into stanzas) of $P k$; stanzas 6 and 7 (1l.21-8) correspond exactly. Stanza 5 of Panskaj Polščy stands out as the principal new material. The reverse side of Panskaj Polščy (fig. 19) is heterogeneous in nature. The first half of the page consists of verses conveying roughly the same kind of anti-Polish sentiment; indeed, some lines from here are to be found in $P k$. The remaining 19 lines, some of which have been deleted, are quite different. Of a satirical nature, they begin with the description of various characters during a theatre interval.

The signed MS of Kołas's article Mova Eyńkova pa ramanu 'Na čyrvonych ladach' is neatly written in violet ink on 7 unlined sheets $17 \times 34 \mathrm{~cm}$. (one side only). It was first published in the same year as Łyńkoŭ's novel in a collection Piśmiennik i mova, ed. Andrej Aleksandrovič, Minsk, 1934, and is reprinted from there in $Z t$. However, both these editions omit Kołas's last seven lines, which read: 'Several of the words adduced here as provincialism may be freely used and introduced into the literary language, e.g. "biezumstva", "subar", "zhorač", "vobmieham", "nicicca", "apoǔźliki". This may be credited to Łyńkoǔ as a positive feature'. One possible explanation is that 'biezumstva' does not appear to be in Kołas's earlier list. Zt (XI, 1517) also omits the heading 'Examples of vulgar naturalism' which should introduce Kołas' illustrations of Łyńkoŭ's 'naturalistic', 'pornographic' style, which he condemns for including references to parts of the body and natural functions. Without this heading the examples that should follow it come straight after a handful of unexplained Yiddish words, and the passage's 
sense is obscured. Finally, $Z t$ shows greater respect than Kołas by adding Łyńkoǔ's first initial ' $M$ '.

An unpublished signed but undated MS entitled Padumajcie ab dzieciach! on three sheets of yellowing squared paper $12 \times 22.5 \mathrm{~cm}$. begins neatly, but becomes increasingly untidy with a lot of crossing out (figs. 202 ). On the reverse of the second and third sheets is material entirely unconnected with Padumajcie ab dzieciach!. The latter reflections, which Kołas himself calls 'a cry in the wilderness', again show his keen moral sense, this time in connection with the upbringing of children. More care should be devoted to their physical and moral welfare; for example, they should go to bed in reasonable time and be protected from immorality (such as the depiction of orgies and executions) in the cinema. Kolas's plea is that methodology and sophisticated systems be not allowed to replace common sense and ordinary concern for children's welfare.

The reverse of the first sheet is blank. The reverse of the second sheet (fig. 23) contains some verses, attempts at verses, and dialogue relating to some less than immortal Maładniak poets, using pseudonyms such as Symon Radniany and Jurka Hruk. The reverse of the third sheet (fig. 24) is a fragment of a story, possibly the beginning, about eight-year-old Alonka who wants to go to school, and incorporating a variety of characters such as Cit, Dzied Marcin, and Piatruś Zvanar.

The final piece of marginalia in the collection of the Francis Skaryna Byelorussian Library is a (Russian) travel pass (no. 2618), $17.5 \times 22.5 \mathrm{~cm}$., for Jakub Kołas, signed in Minsk on 4 April 1921 by the Chairman of the Sovnarkom of Byelorussia, Alaksandr Carviakou (1892-1937), and the Secretary of the Central Executive Committee, Vitold Ašmaryn (18821930). Addressed to the Station-master of Klej Michejevo on the MoscowKursk-Sebastopol railway it reads as follows:

'By this document the Sovnarkom of Byelorussia asks you to provide one equipped passenger carriage for the transport from the town of Obojan', Kursk region (station Klej Michejevo) to Minsk of the famous Byelorussian poet Konstantin Mickevic (Jakub Kołas) with his family and belongings'.

The Francis Skaryna Library's collection of Kupała and Kolas materials, ranging from marginalia such as the above travel document to important and sometimes hitherto unknown manuscripts, continues to grow. An exciting very recent (1982) addition has been the MS of an unfinished poem, Antonu Łuckieviču (fig. 25). The sheet of squared paper $12 \times$ $22.5 \mathrm{~cm}$. (similar to that used for Dola batrački etc., see supra) appears to come from a series: there is a figure 9 in the bottom right-hand corner, and the verso (fig. 26), containing miscellaneous prose and verse material, has a figure 8 in the top right-hand corner. Anton Euckievič (1884-1946) political activist and (under the pen-name of Anton Navina) literary critic, characterized by Kolas in 1.15 as a 'sower, good, sincere and conscietious', did indeed tread 'a path without joy' (1.1). It may be hoped that at least this valuable new MS will speed Łuckievič's long-overdue rehabilitation.

The Library's collection is, thus, clearly a very significant holding which should be of both academic and general historical interest. It represents a valuable part of what is now one of the richest collections of Byelorussian books and materials in the world. 


\section{Notes}

1. For the fullest account of the Library's holdings see Alexander Nadson's descriptio $n$ in The Francis Skaryna Byelorussian Library and Museum 1971-1981, published by the Library, London, 1981, pp.7-18.

2. Although the Byelorussian Latin orthography is used throughout this description, the manuscript of Kurhan is in fact in Cyrillic. However, a reminder that the choice of scripts was still in the balance at this time is provided by 1.176 of the poem where Kupała wrote the first two letters of 'slub' in Latin script before crossing them out and carrying on in Cyrillic. A further example of this co-existence of two scripts is seen in Kupała's proofs of Maładaja Bietaruś (see infra). See also the two MSS of Kolas's Druhoje čytannie (infra). It was, in fact, Kupala himself who helped to tilt the balance in favour of Cyrillic when, after 24 October 1912, Naša niva (hereafter $\mathrm{Nn}$ ) ceased to publish a dual version. For a discussion of the issues involved see the special correspondence column in issues $4,5,6$, and 8 of $N n, 1912$ entitled 'Hutarki z cytacami. Jaki šryft?', and in particular the contributions of J. M-ski [Janka Kupała].

3. The reasons for the delay are not clear.

4. Janka Kupała, Zbor tvoraú u siami tamach, ed. V.V. Barysienka et al., Minsk, 1972-6 (hereafter $Z t$ ), V, pp.509-10.

5. In all, 42 lines in the manuscript version are corrected or amended. in some cases more than once.

6. Janka Kupała, Vybranyja tvory, ed. M. Klimkovič, Minsk, 1936 (1935 on the title page), pp.30-40.

7. See S.A. Klepikov, Filigrani na bumage russkogo proizvodstva XVIII - načala XX veka, Moscow, 1978, p.214 no.1235).

8. For an illustration of the polemic about the attitudes of these two periodicals see A.U. [almost certainly Aleksandr Ułašcyk, one of the founding members of Nasa niva], 'Apiekuny i darosłaje dzicia', $N n, 15$ February 1913, p.1.

9. See also Aleś Barščeǔski, 'Našaniǔskaja para: Janka Kupała - castka XLШ', Niva, 1 e3 December 1981.

10. I. Dvarčanin, Chrestamatyja novaj bietaruskaj literatury (ad 1905 hodu),Vilna, 1927, pp.274-6.

11. Ibid., p.273. Ruta is not included in this anthology.

12. See note 2 .

13. The first reader had been prepared by Ciotka (Aloiza Paškievic): Pieršaje čytańnie dla dzie tak biełarusaǔ, St Petersburg, 1906.

14. Curiously, $Z t$ states in its note on this collection (IV, p.330) that the MS bears the date 'April 1907'.

15. See, for example, the MS of Pryzyv (1904) or some of his folklore collections illustrated in D.K. Mickievič et al. (eds), Jakub Kołas. Žyćcio $i$ tvorčaść, Minsk, 1974, pp.36 and 38.

16. Jakub Kołas, Druhoje čytańnie dla dziaciej biełarusaŭ, edited and with an Introduction by L. Sieǔruk, St Petersburg, 1909.

17. Zt, IV, p.330.

18. Pole was first published in Volnaja Biełaruś, 1917, no.4 (24 June). In Vodhulle (Minsk, 1922) it is dated 27 August 1916. 


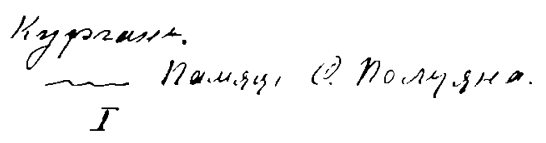

12 aruse myernax, dacom desapyexaer zursi,

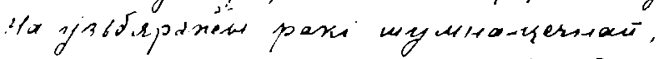

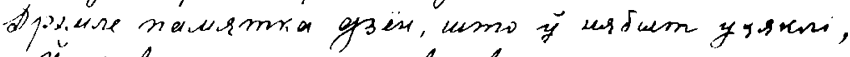

ÿgziplaseses kyprias beraberes.

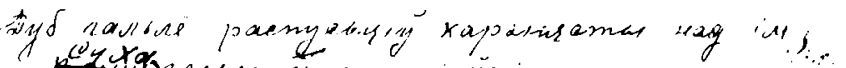

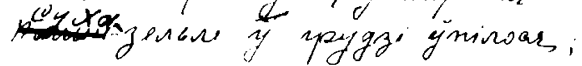

keyep emonses irag im yzgusasesues nsysice, $i,-$

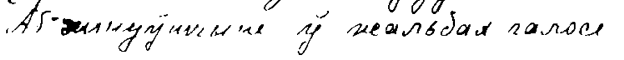

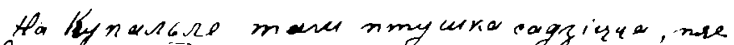

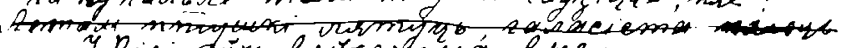

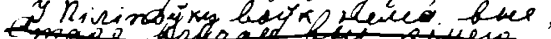

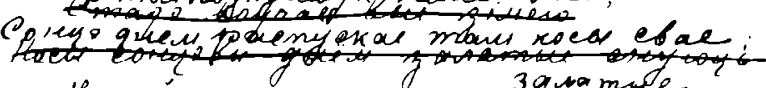

Honkol jopal nsigzsys 3awambe.

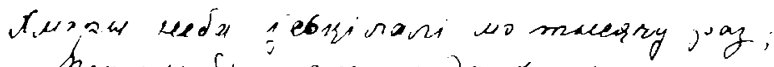
hopyiem Sinin e ropous da kpor:

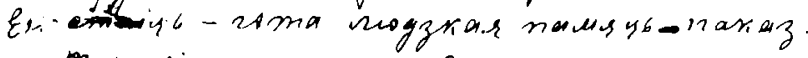

Monori nymapa Mogze maxar.

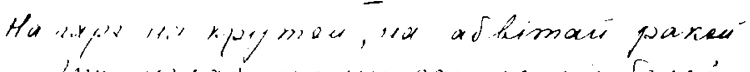

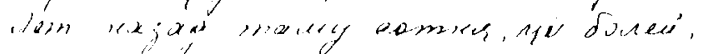

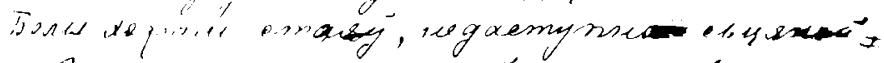

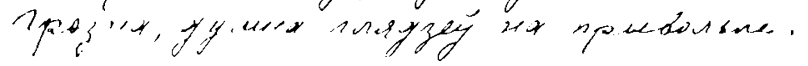

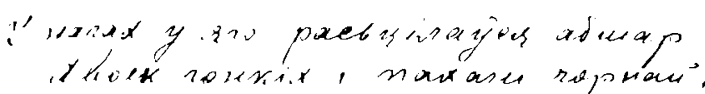

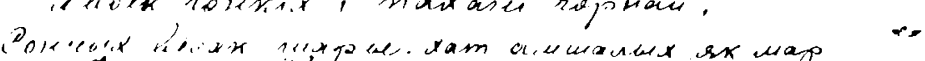

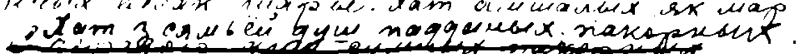

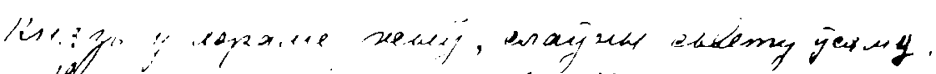

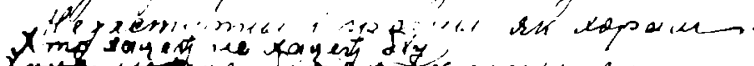

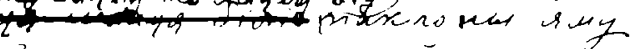

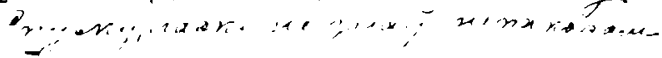

$=$

fig. 1. Janka Kupała, Kurhan, p.1 


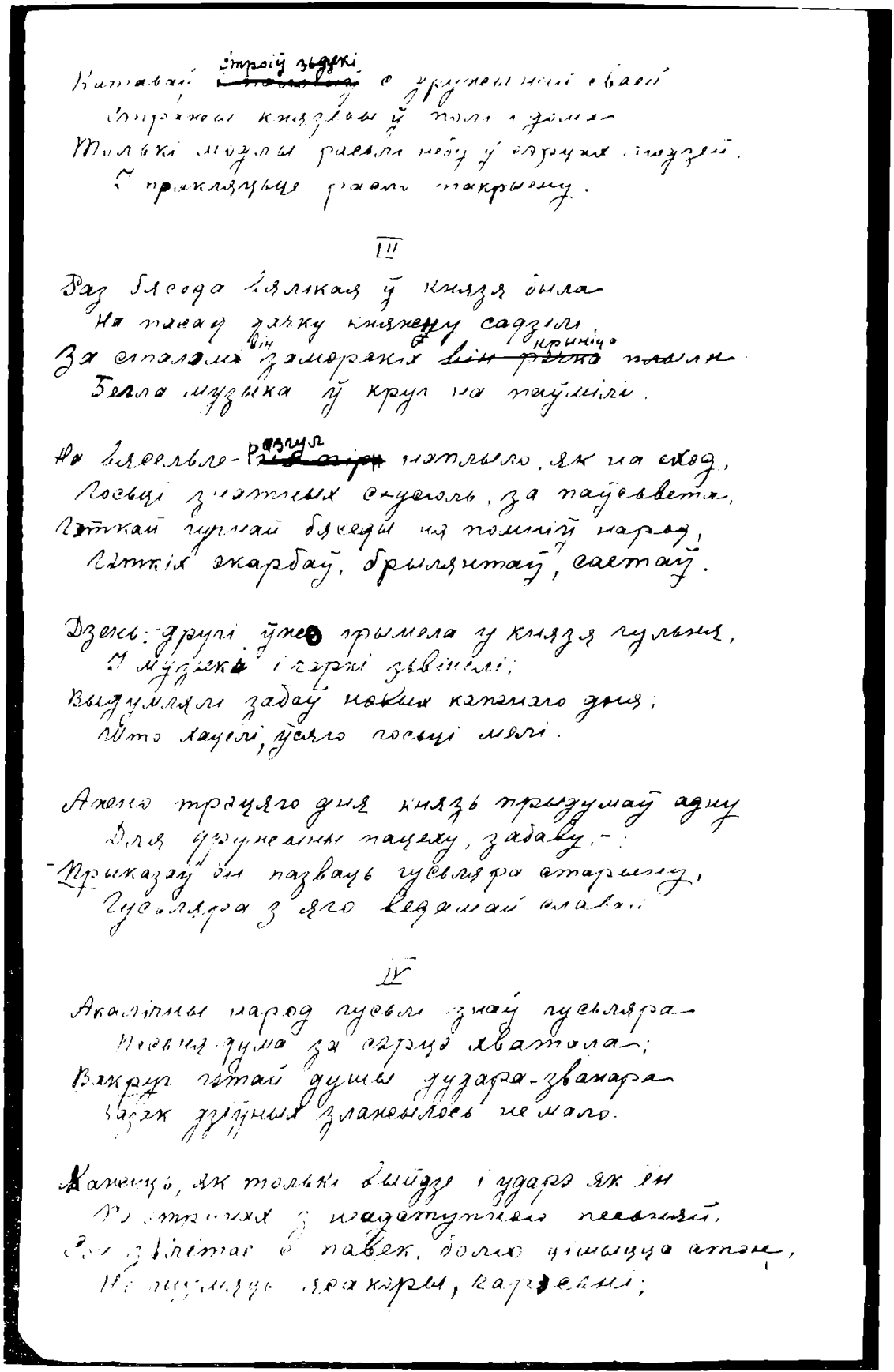

fig. 2. Kurhan, p.2 


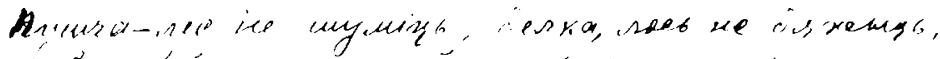

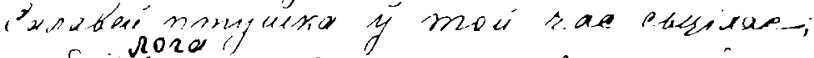

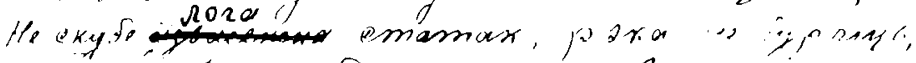
naniaym yofo nismxo wabaes;

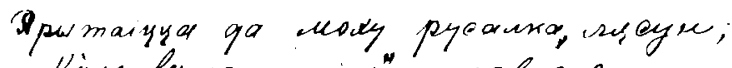

Haiss lesiaco" niy" hep gabogze.

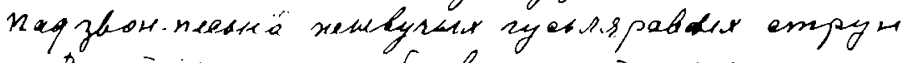
thes jeit manayous-xhemro jizberogze.

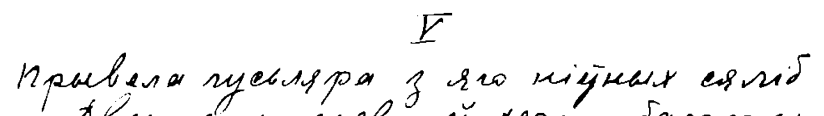
Dhopser kreszeba y̆ xpeace Saraman, nacagini wa hasesy, wixe kasimay inin. Ho ydísesur napozs wankama.

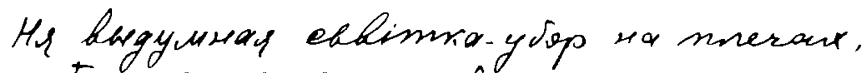

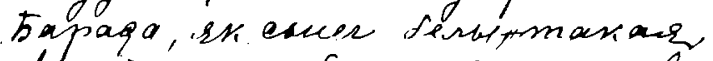

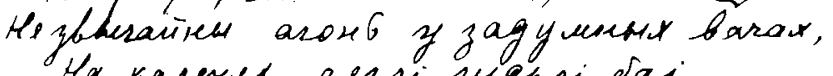
Ho racesut sasui zyebri-sai.

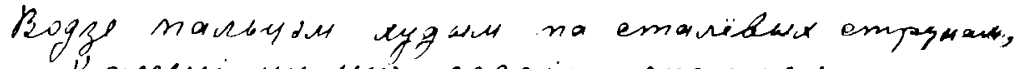

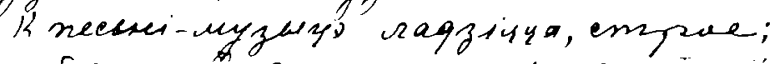

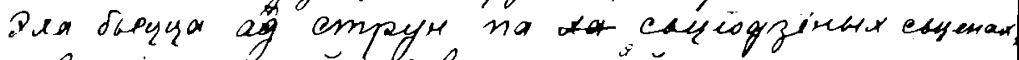

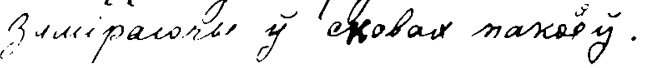

Boes rasmpoin, wabiy mos y ampyrax, sx chreg,

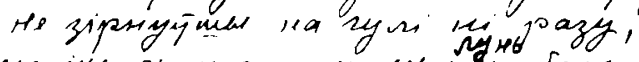

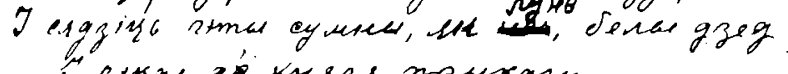

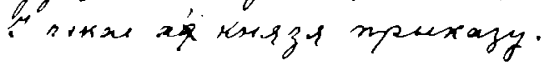

\section{EI}

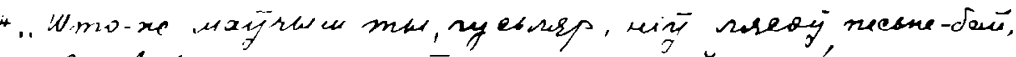

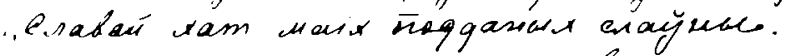

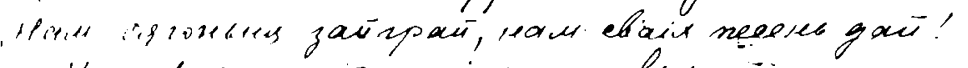

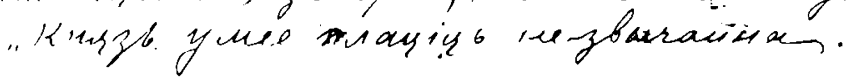

fig. 3. Kurhan, p.3 


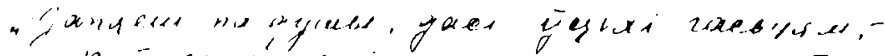

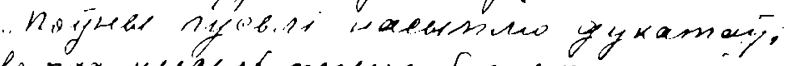

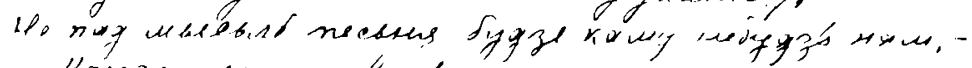

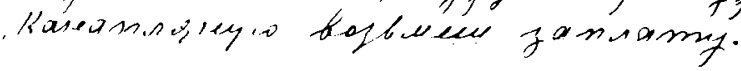

3rapen eraby mano, zwaes eing wano,

"Mresa ghaw i ryy af mave s.

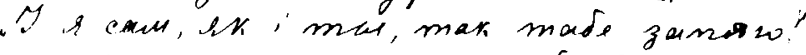

"thy, napon waskesianb, qadpogzes!".

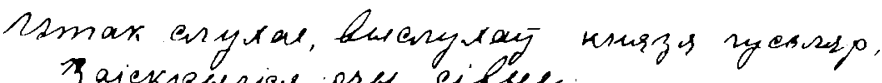

3 aiekjownies orw eilke,

1.

\section{$\underline{Y I I}$}

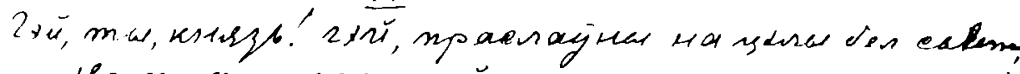
He maxyeo zagrumai mu

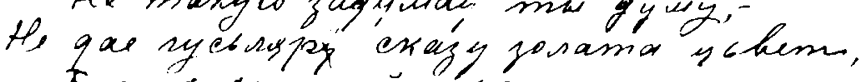

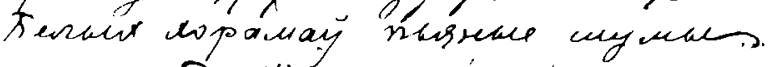

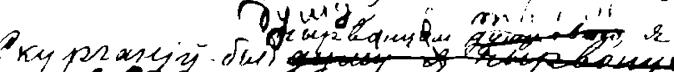

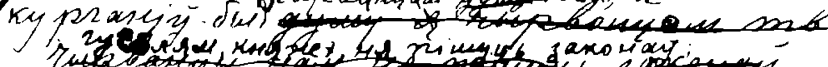

1 of

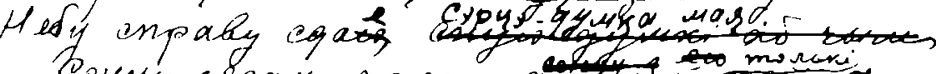

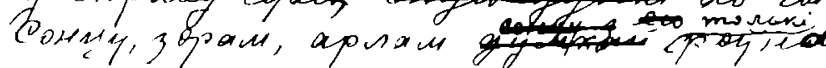

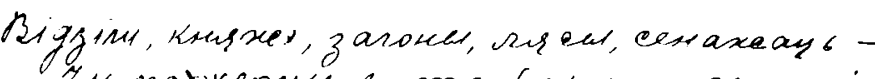

In maxkppsew if monbxi z ngesspui.

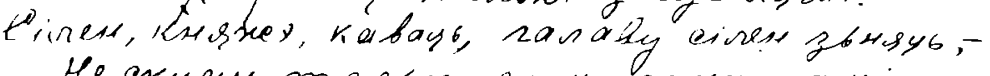

He oxyere m-onkre gyw inasizyromi.

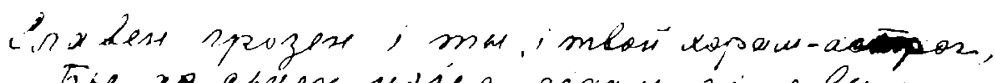

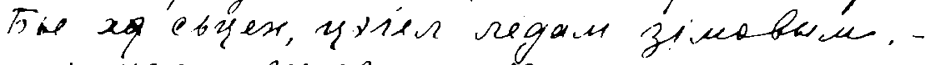

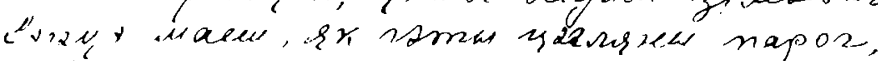

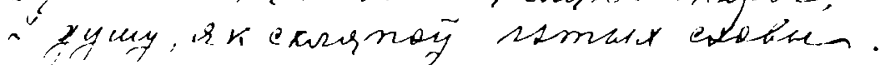

fig. 4. Kurhan, p.4 


\section{$\ddot{r} / 1$}

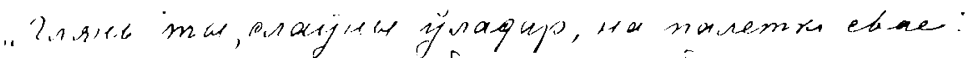

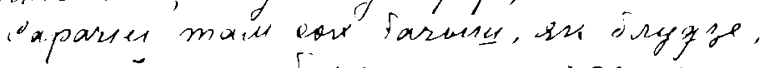

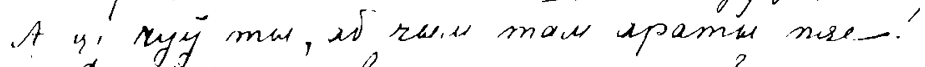

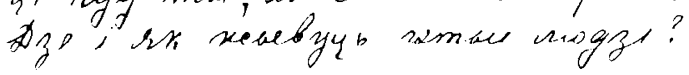

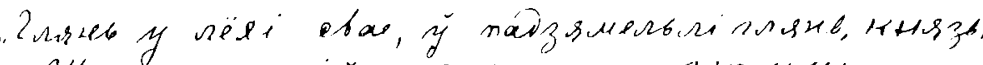

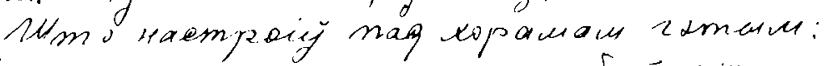

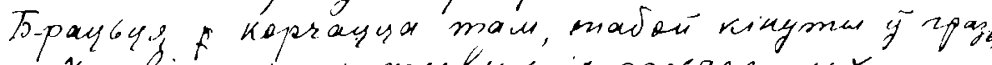
ixpli mory 46 neweker itppazagzemact.

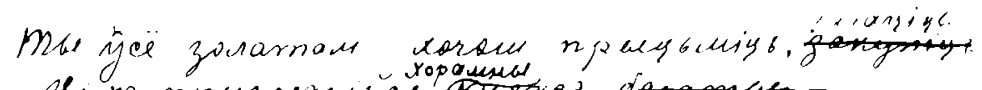

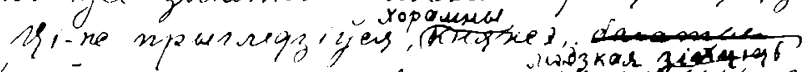

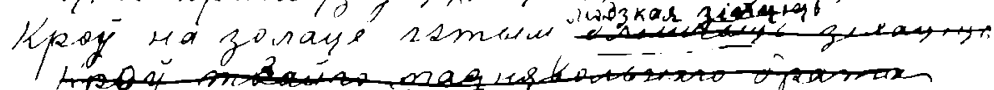

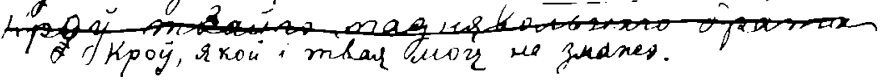

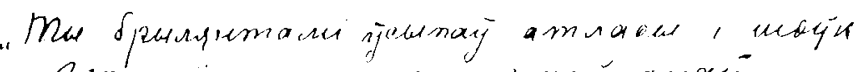

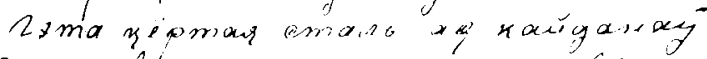

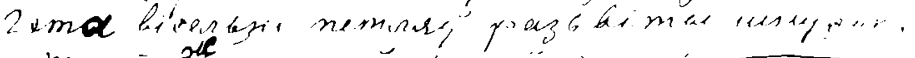

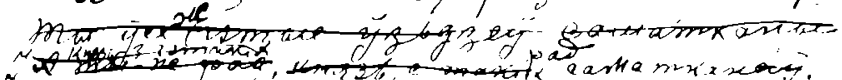

a

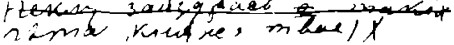

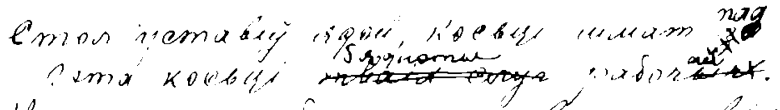

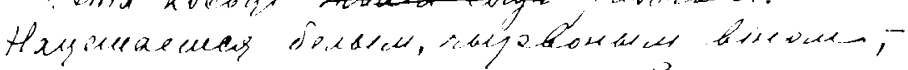

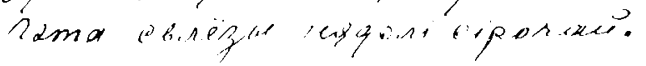

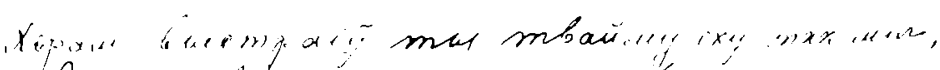

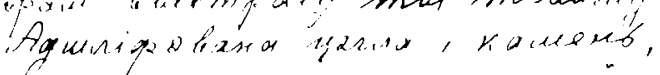

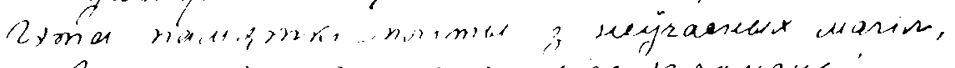

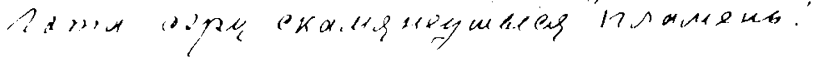

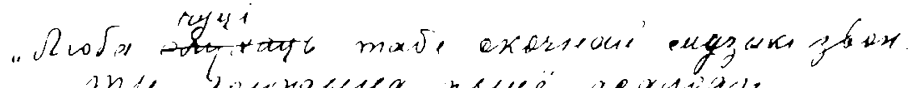

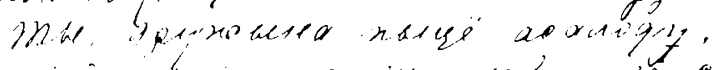

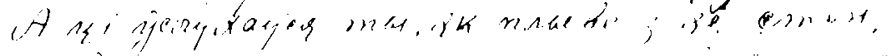

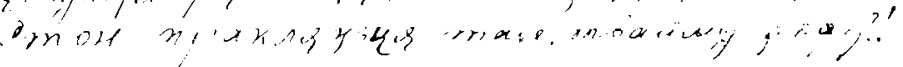

fig. $\quad 5 . \quad$ Kurhan, p.5 


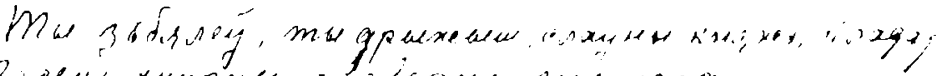

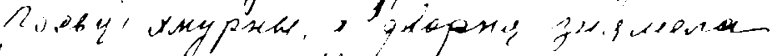

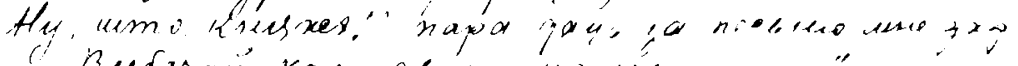

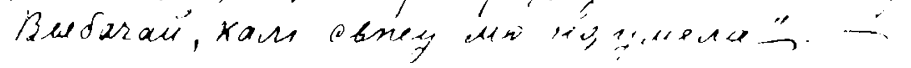

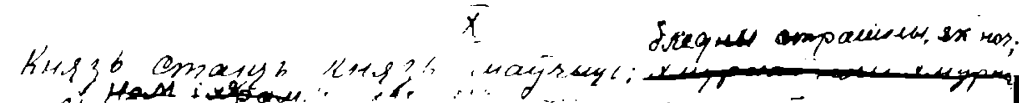

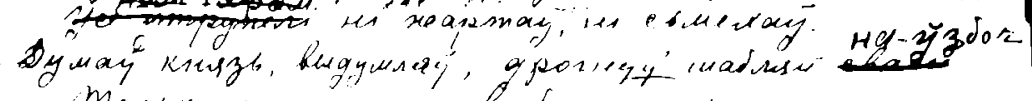

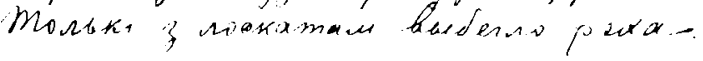

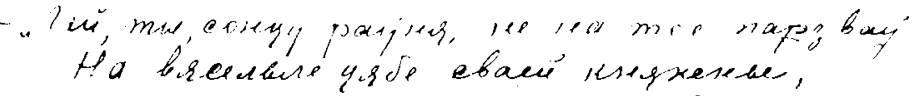

mis manerw pmapux; tmo ysj 930 ix 8 aj

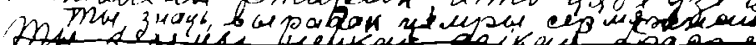

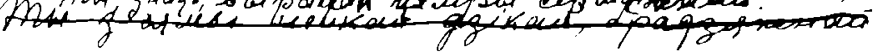
$\left.\eta_{n}\right)$ agbanesryer

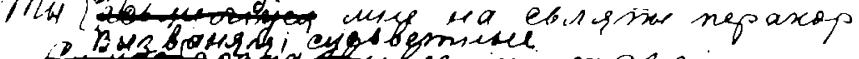

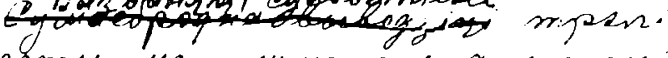

llnami cuavo unam is gus manit resnaks,

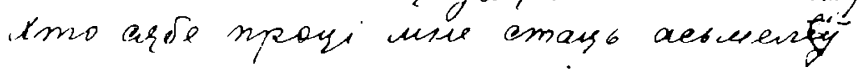

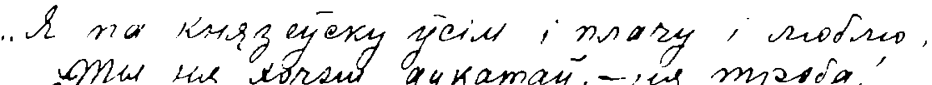
mow the torsul gykamay,-ies mosor.

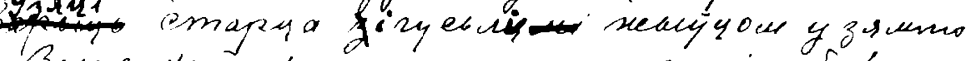

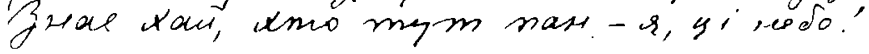

\section{$\overline{X T}$}

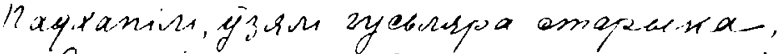

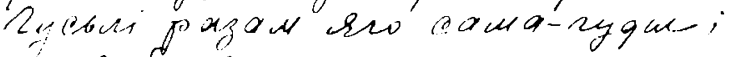

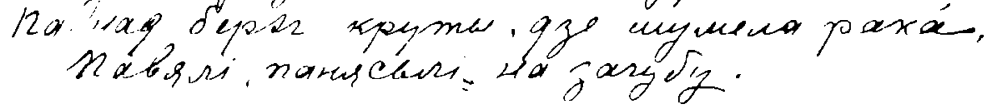

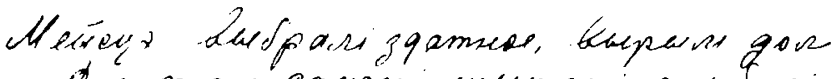

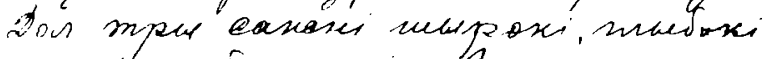
Jaxanain, yfis asinoble kor, Banitadew mpu sament baceari.

fig. $\quad 6$. Kurhan, p.6 


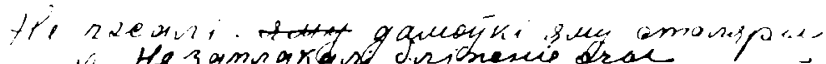

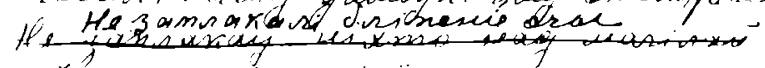

).

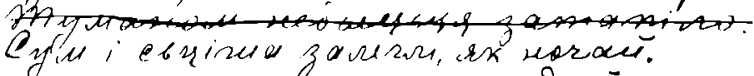

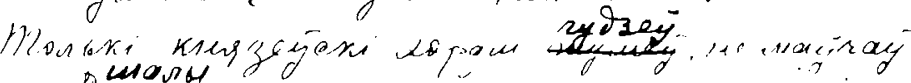

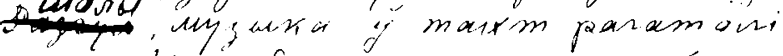

the

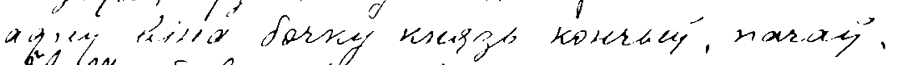

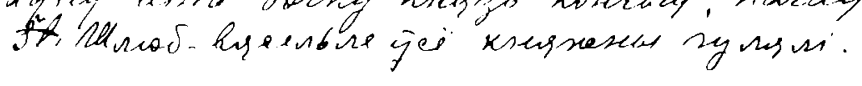

\section{XII}

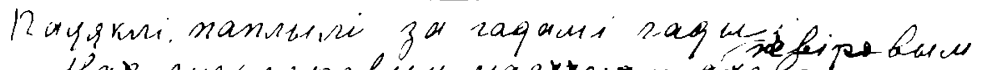

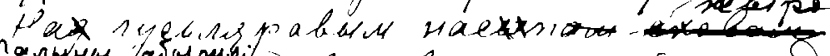

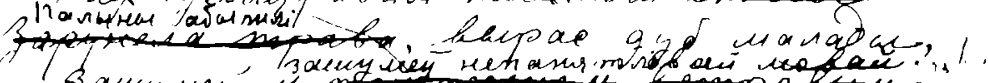

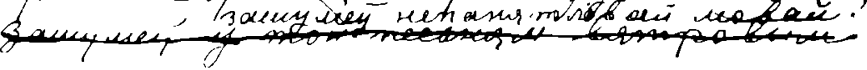

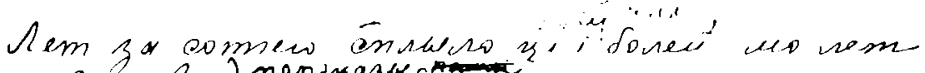

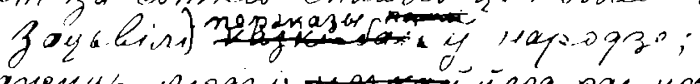

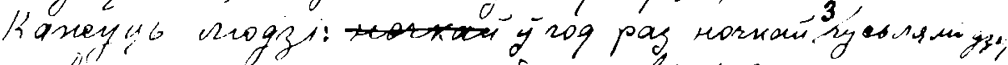

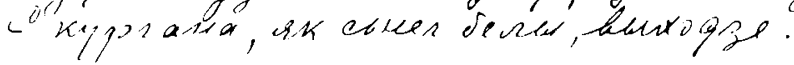

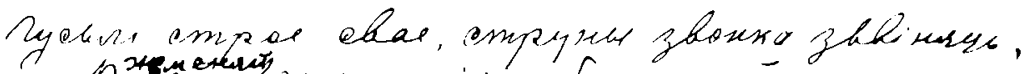

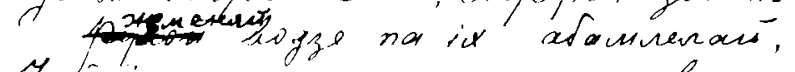

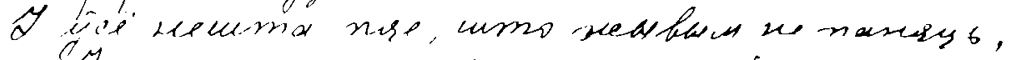

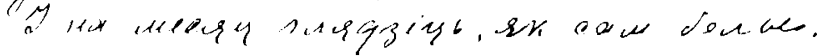

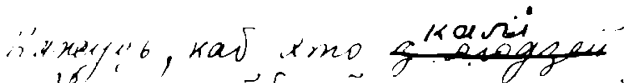

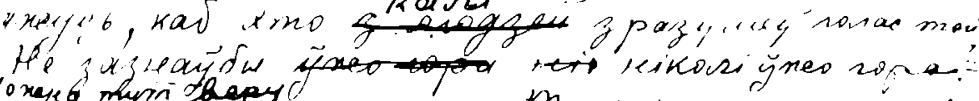

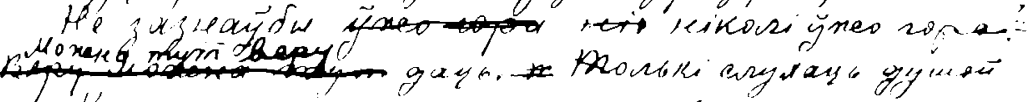
líppinsen suriam raso wam subopeyso. 2310

fig. 7. Kurhan, p.7 


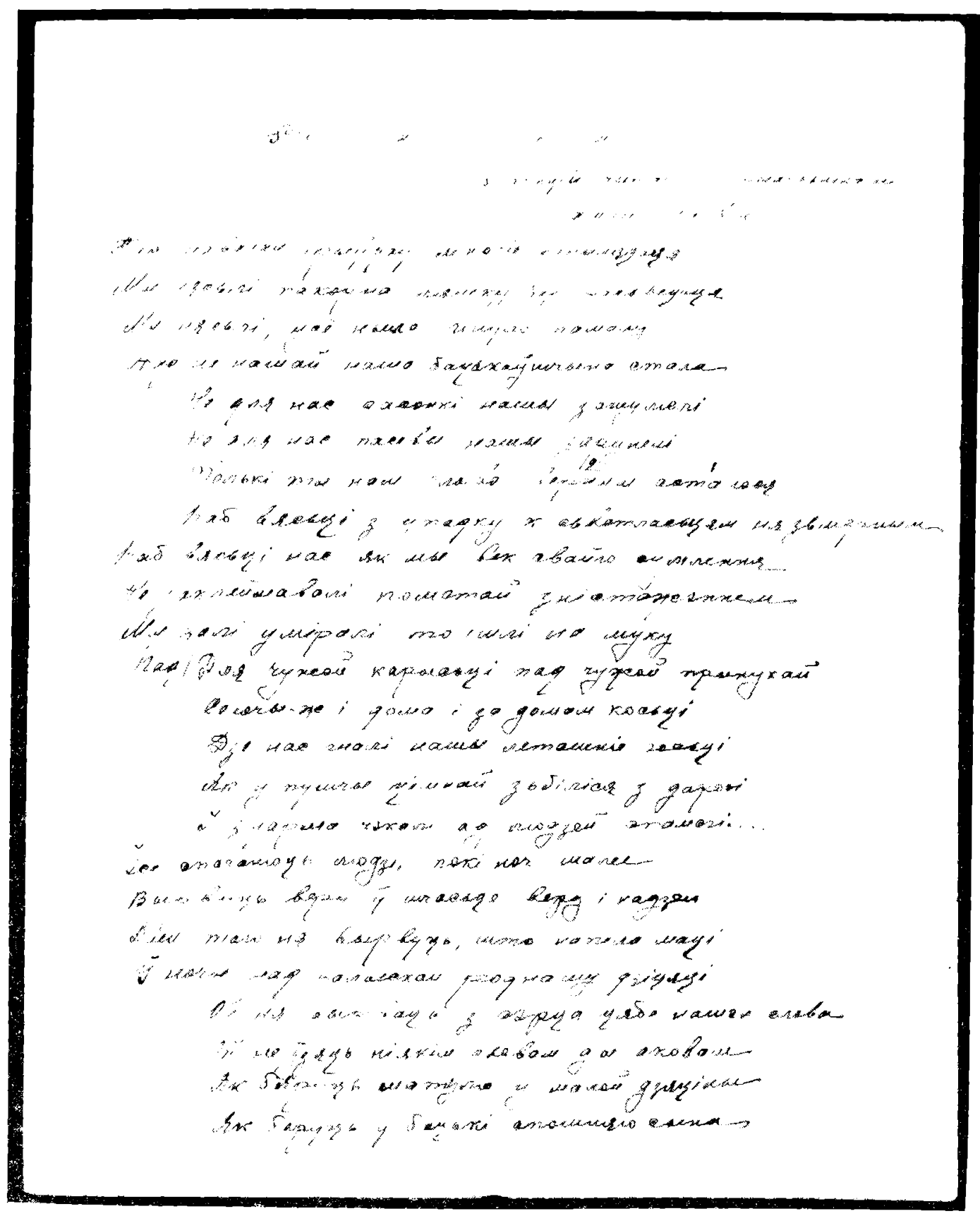

fig. 8. Janka Kupała, Rodnaje stova, p.1 


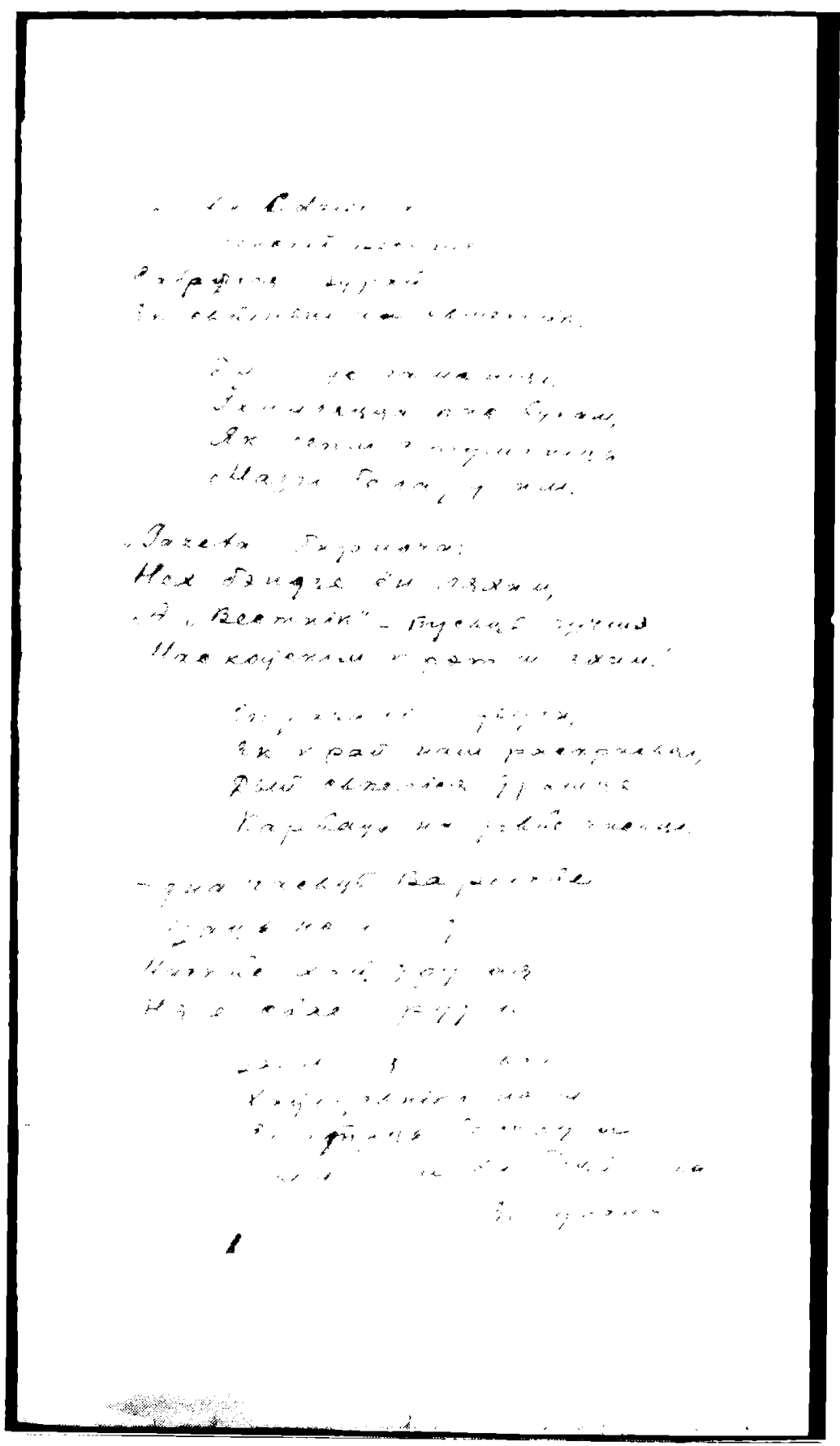

fig. 9. Janka Kupała, Chaŭruśnikam 


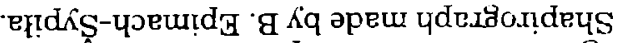

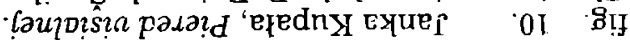

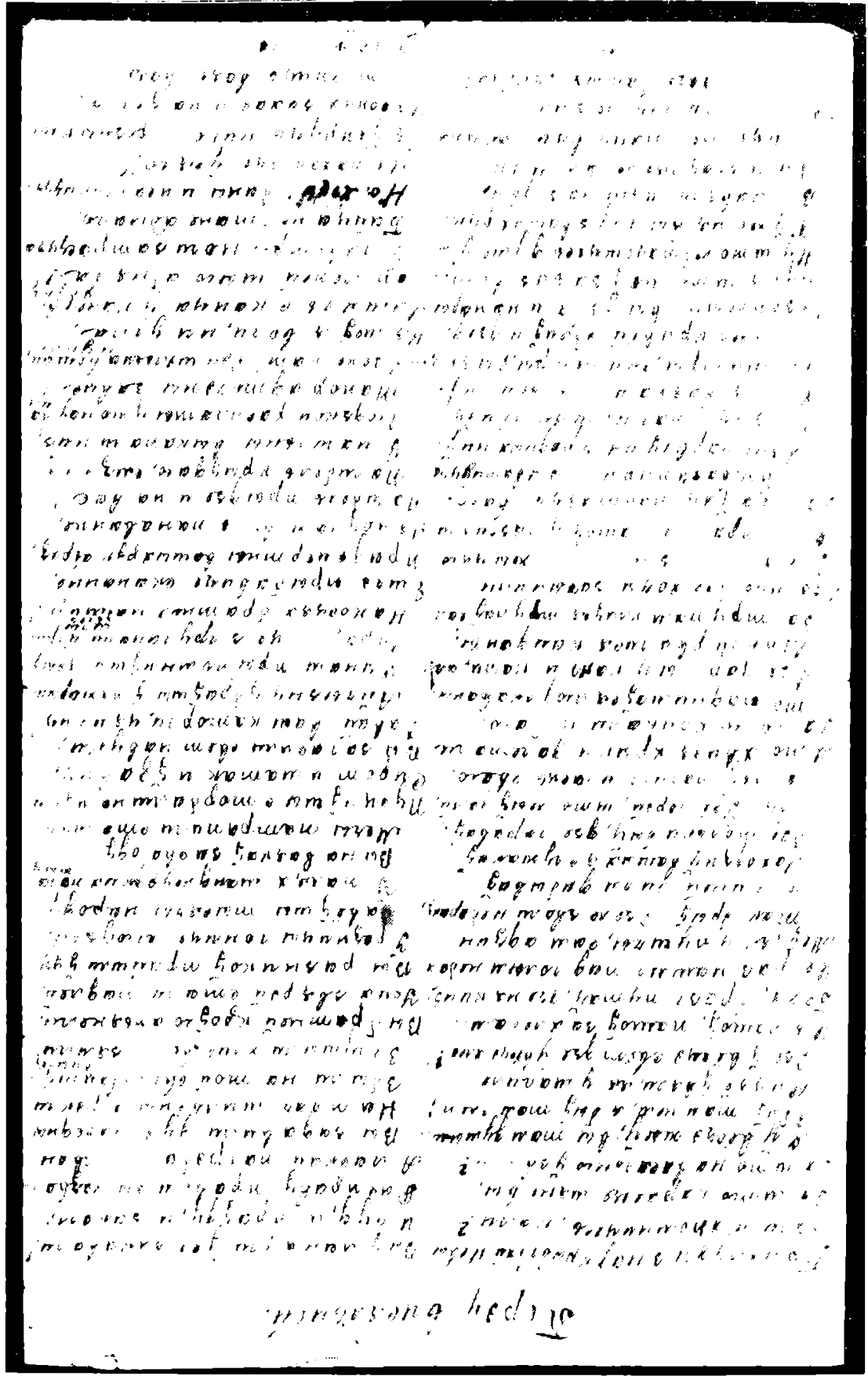




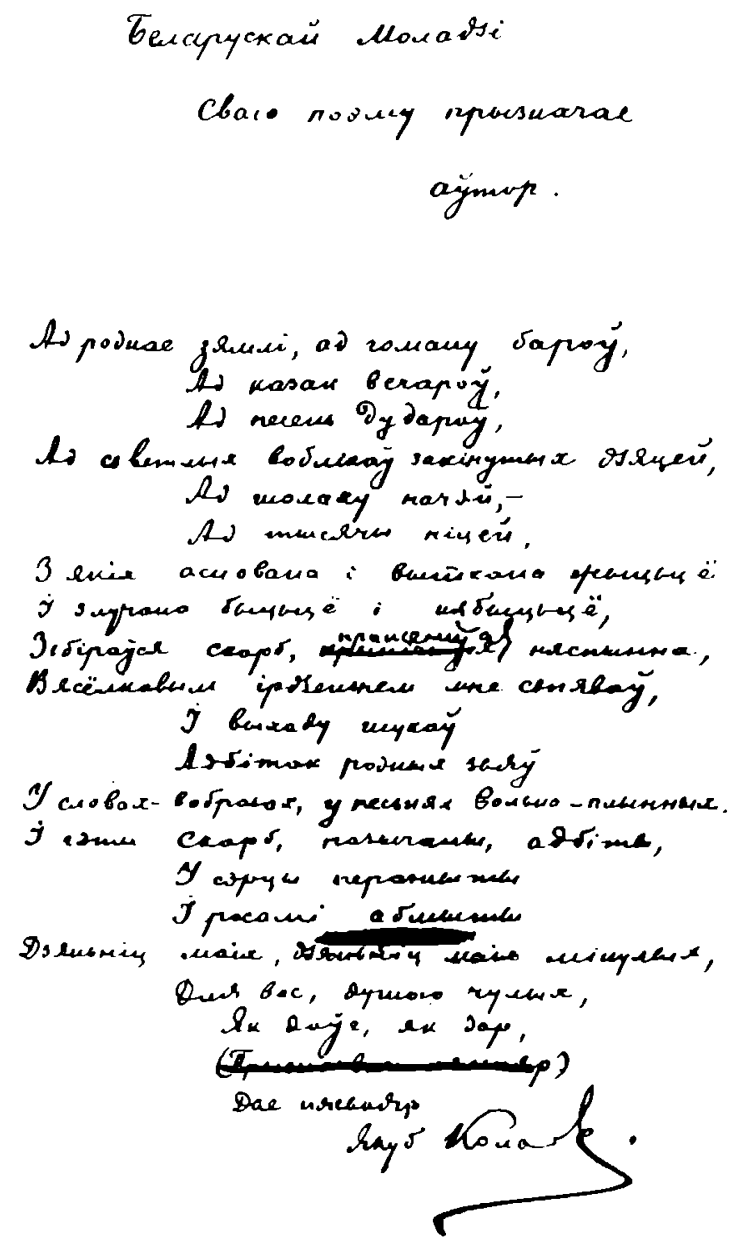

fig. 11. Jakub Kołas, Introduction to Symon-muzyka 


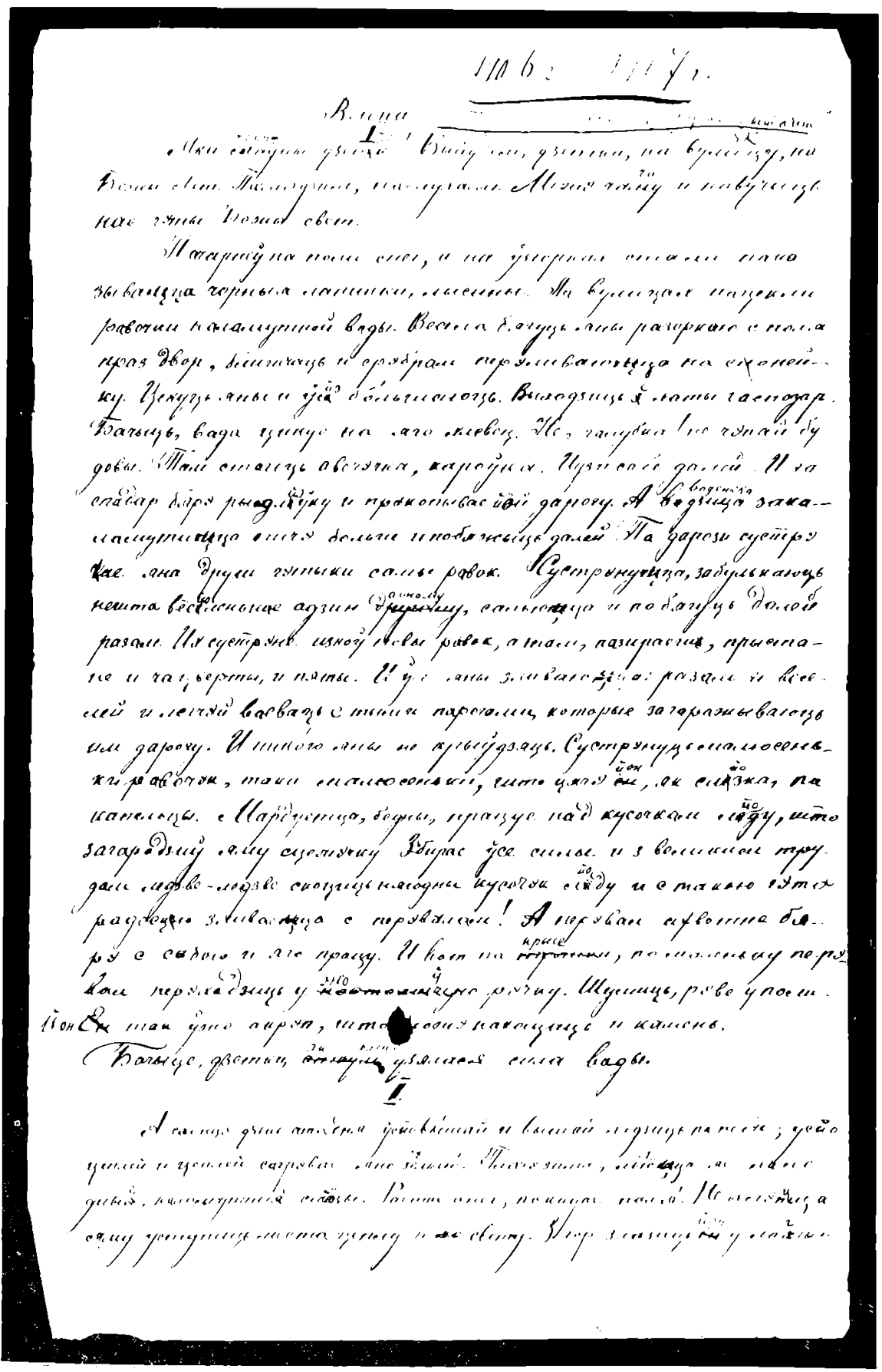

fig. 12. Jakub Kołas, Druhoje čytańnie dla dziaciej biełarusaŭ, p.1 


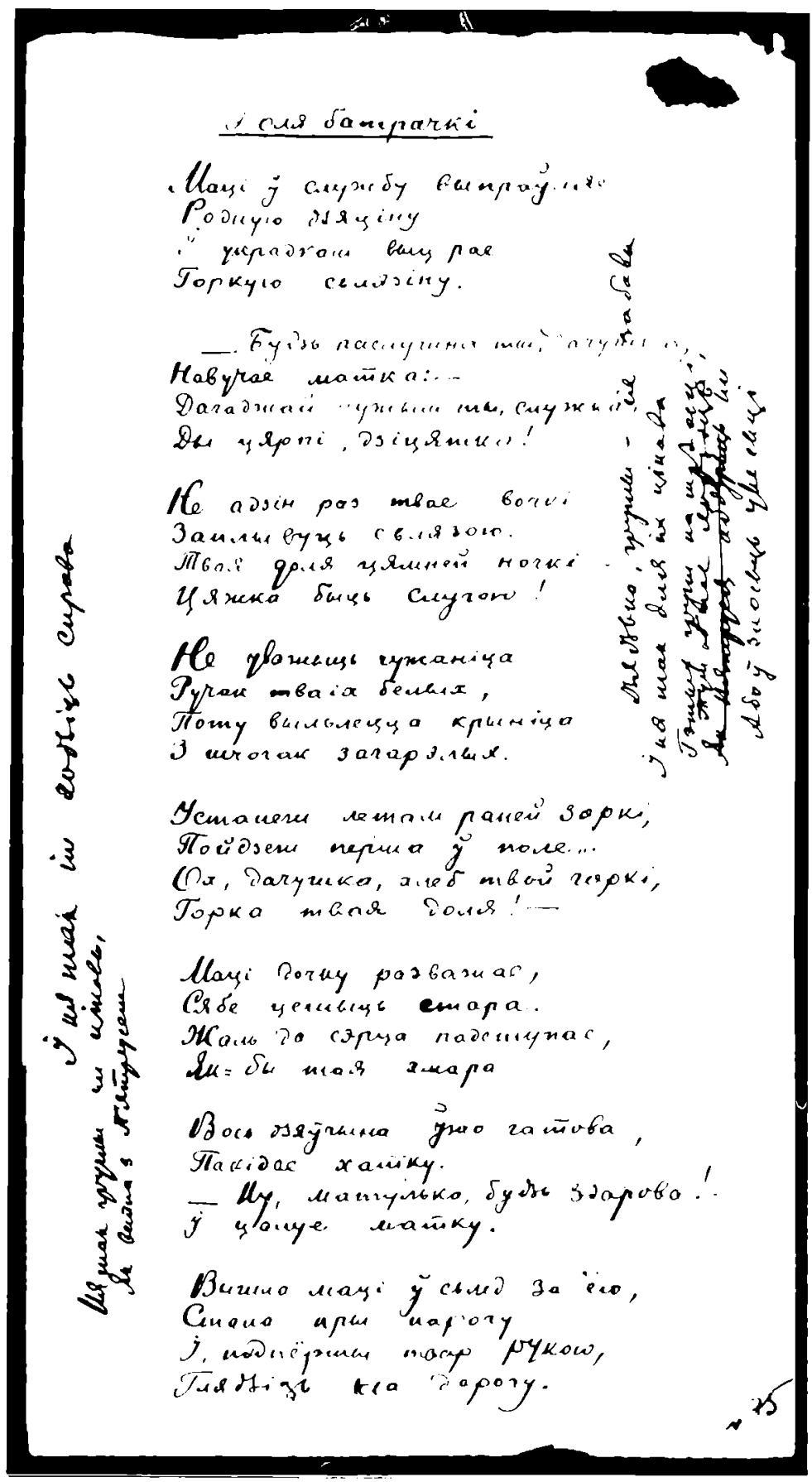

fig. 13. Jakub Kołas, Dola batrački 


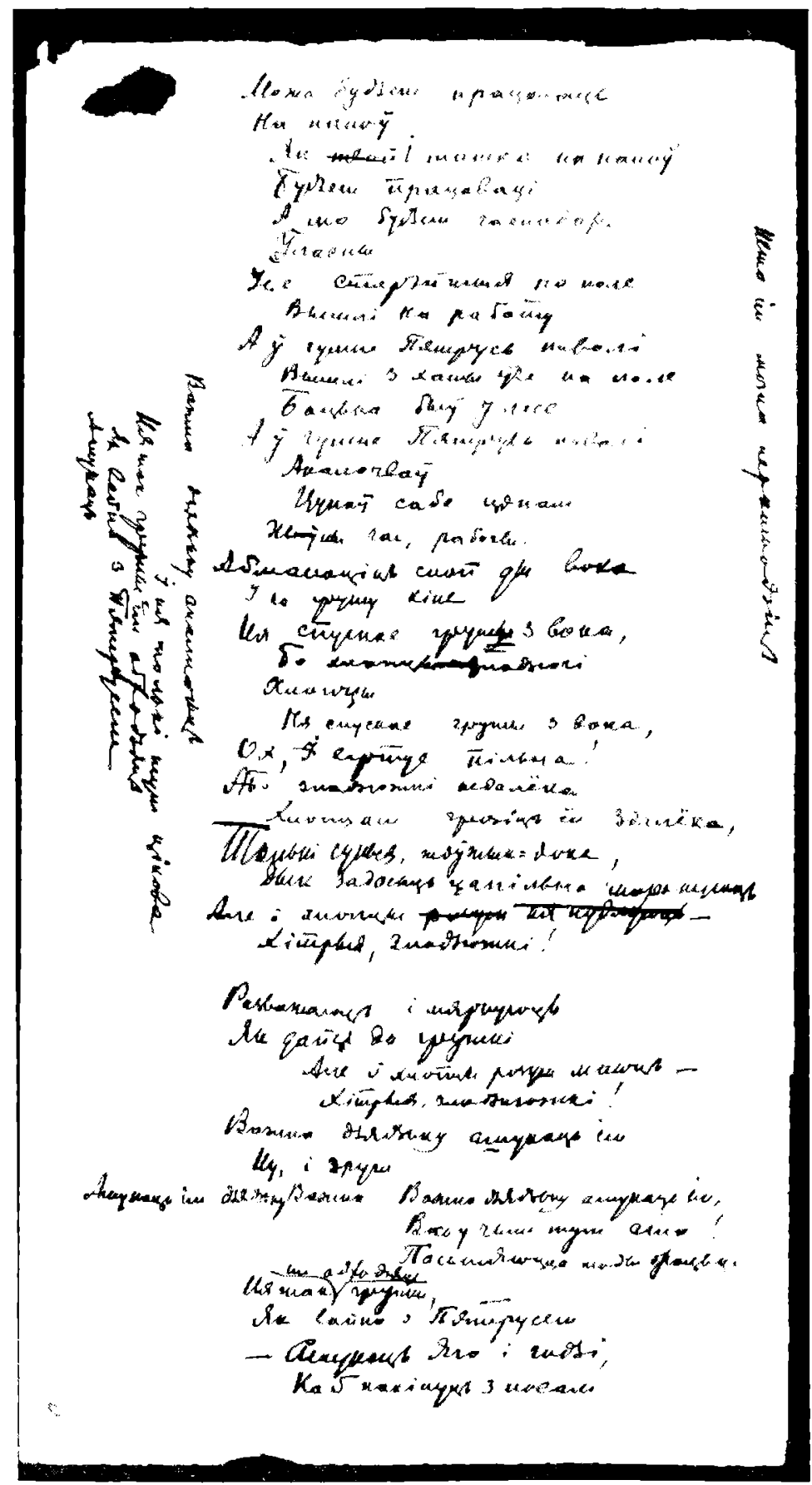

fig. 14. Verso of Dola batrački 


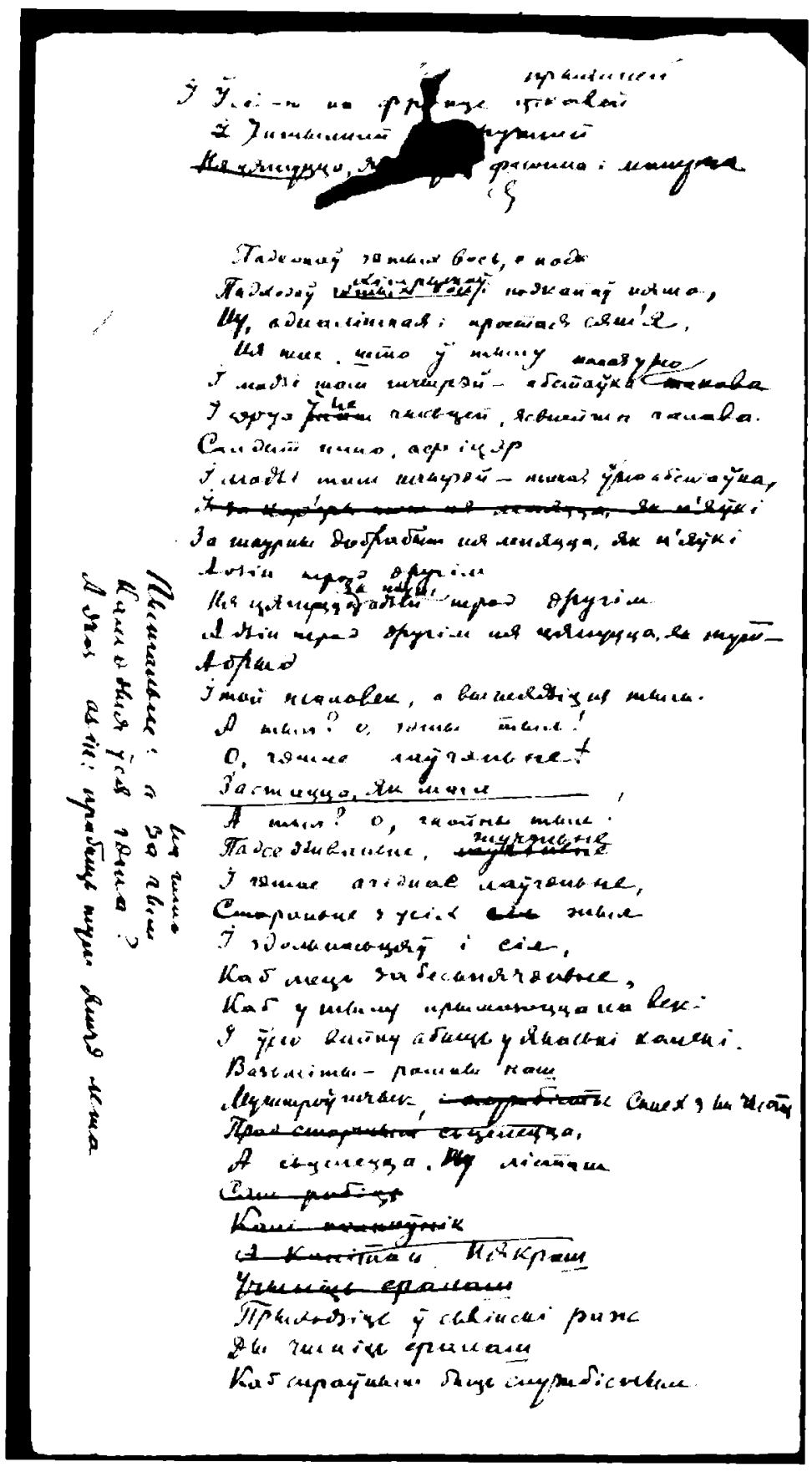

fig. 15. Verso of Jakub Kołas, Pole 


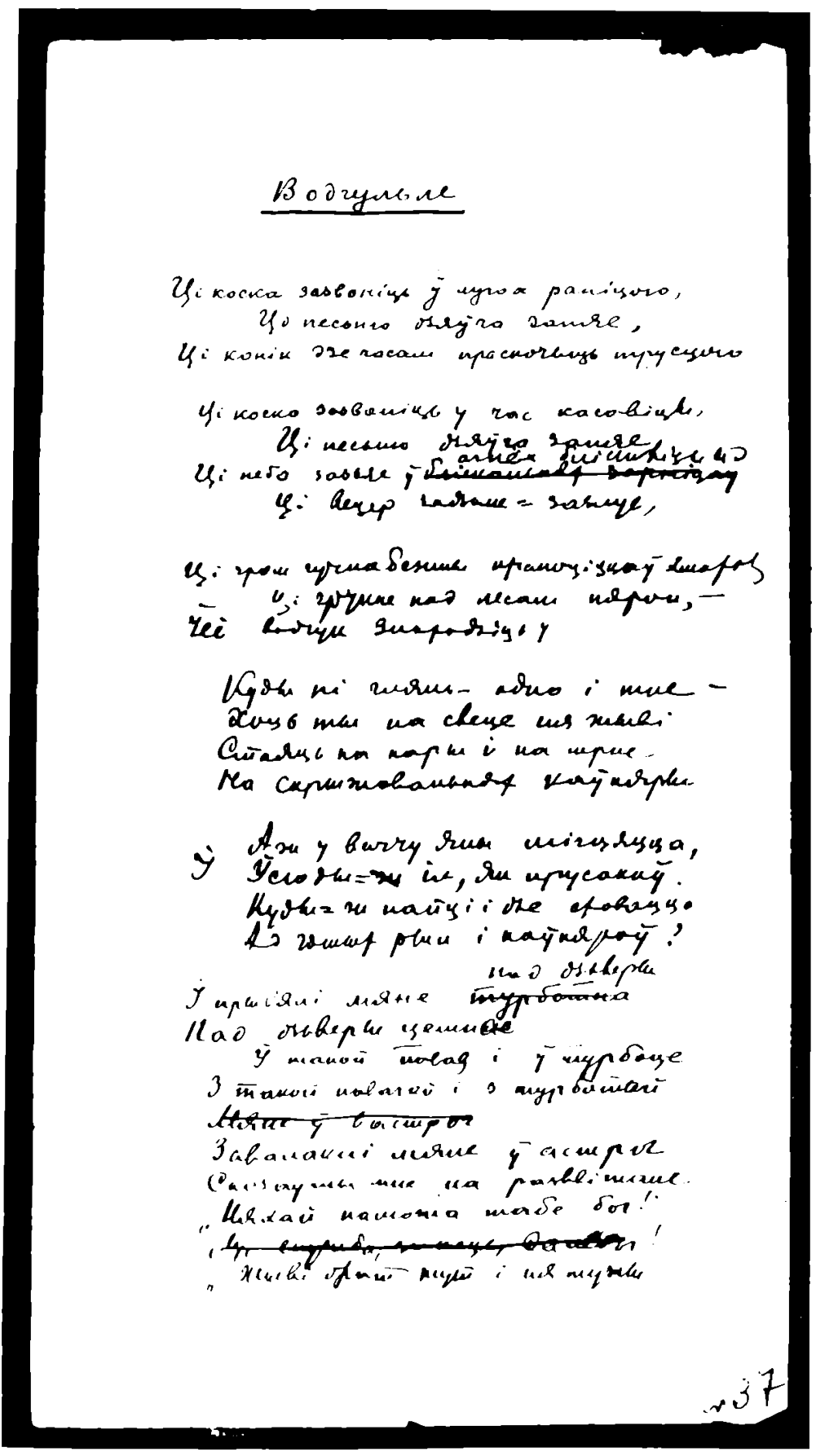

fig. 16. Jakub Kołas, Vodhulle 


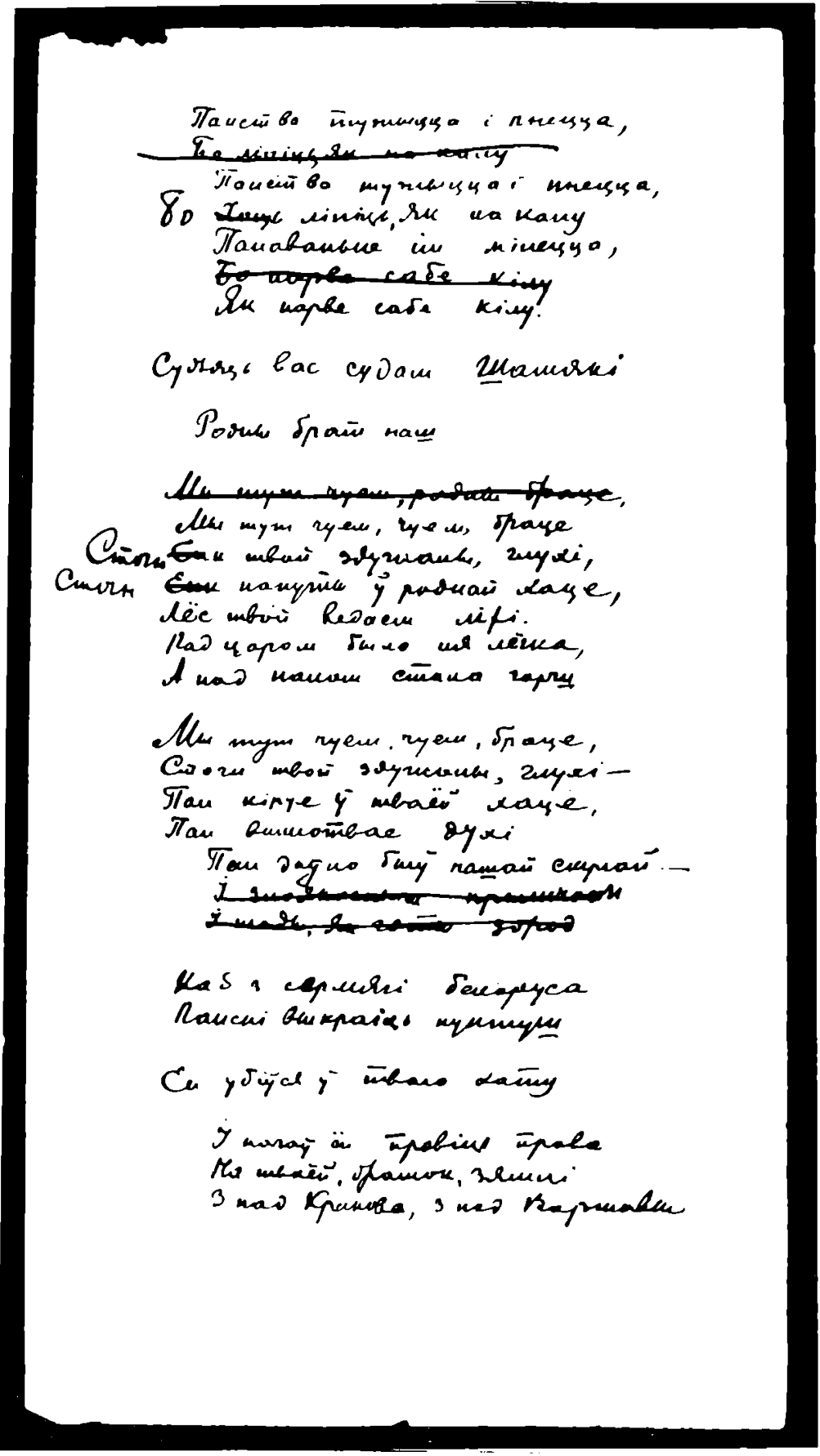

fig. 17. Verso of Vodhulle 


\section{Trercani: Tosurem \\ Puystends}

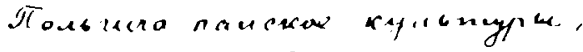

Fonstura - Silese Oyponter-

3avilue "nypungey mypt

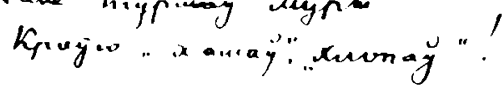

ta

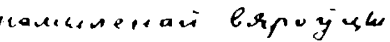

Hober "yy" Buprualen-

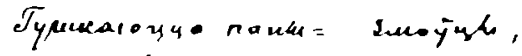

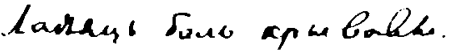

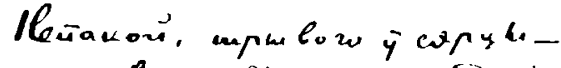

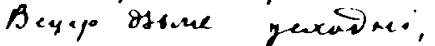

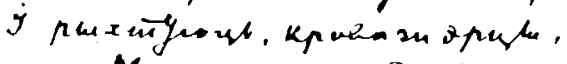

Ma yехuक nixadmi.

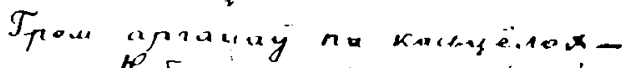

A ux mecimax,a na cëmx

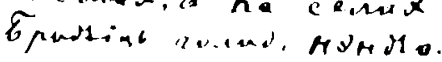

y Kabarpýpy, y Kinкn.

To gicix nowberis. lípyest

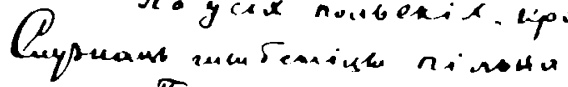

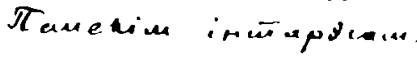

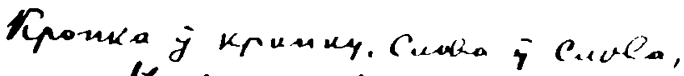

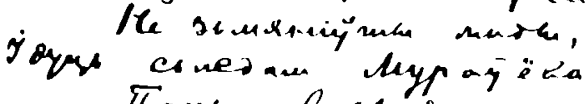
Tancu = Rarbale

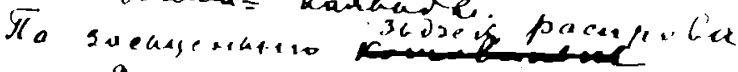

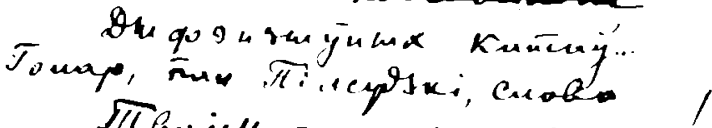

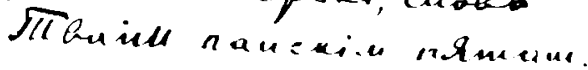

$$
\angle P \times 11 / 4 / 1
$$

fig. 18. Jakub Kołas, Panskaj Polščy 


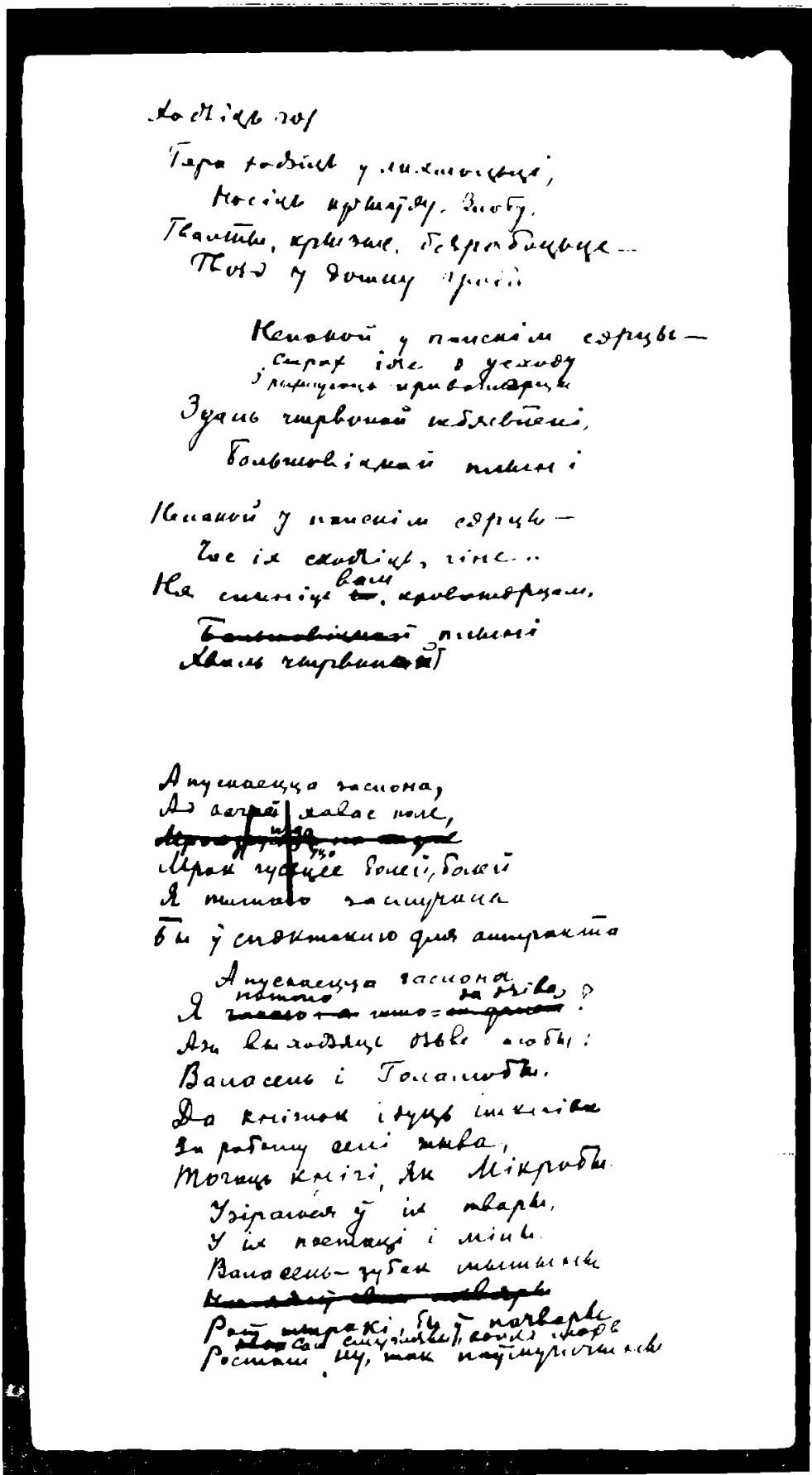

fig. 19. Verso of Panskaj Polščy 


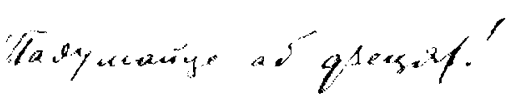

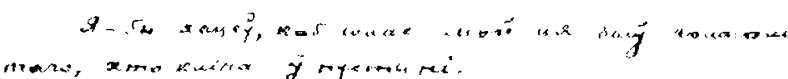

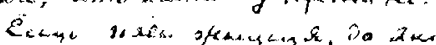

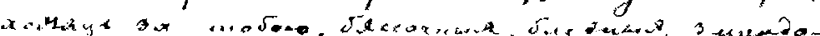

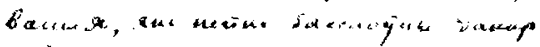

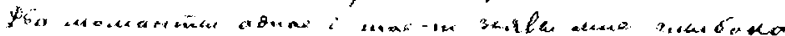

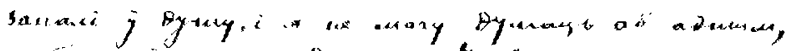

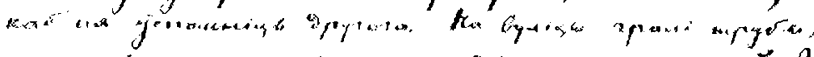

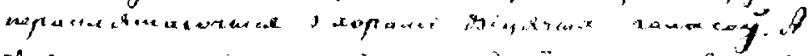

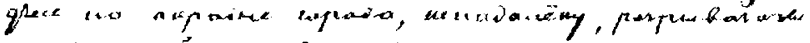

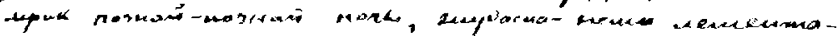

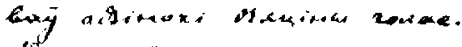

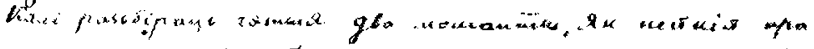

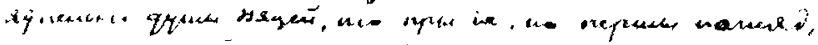

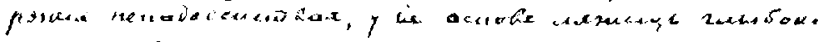

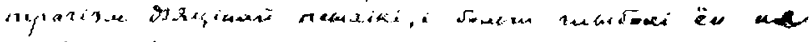

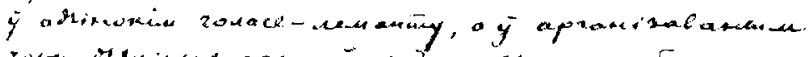

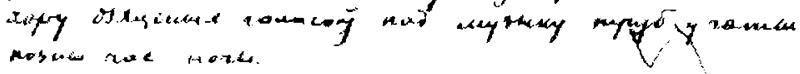

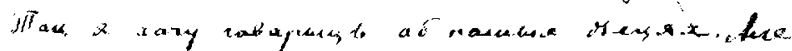

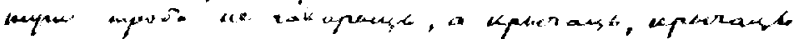

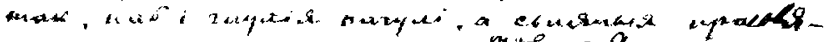

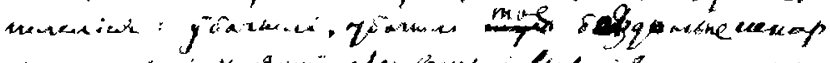

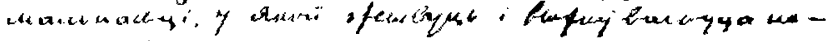
Len Meng:

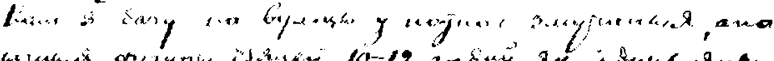

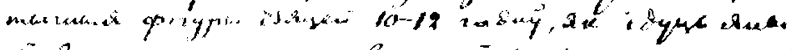

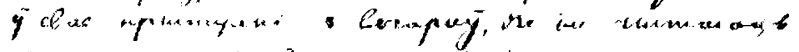

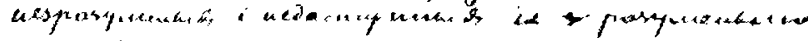

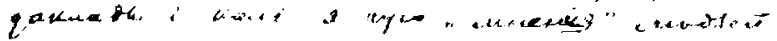

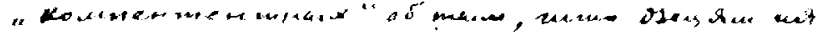

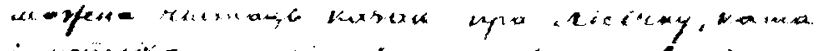

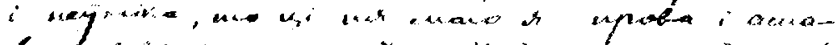

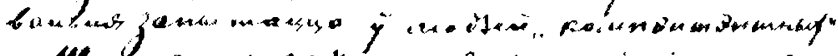

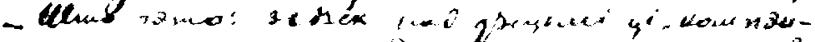

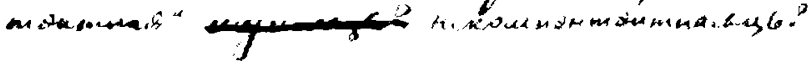

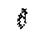

fig. 20. Jakub Kołas, Padumajcie ab dzieciach!, p.1 


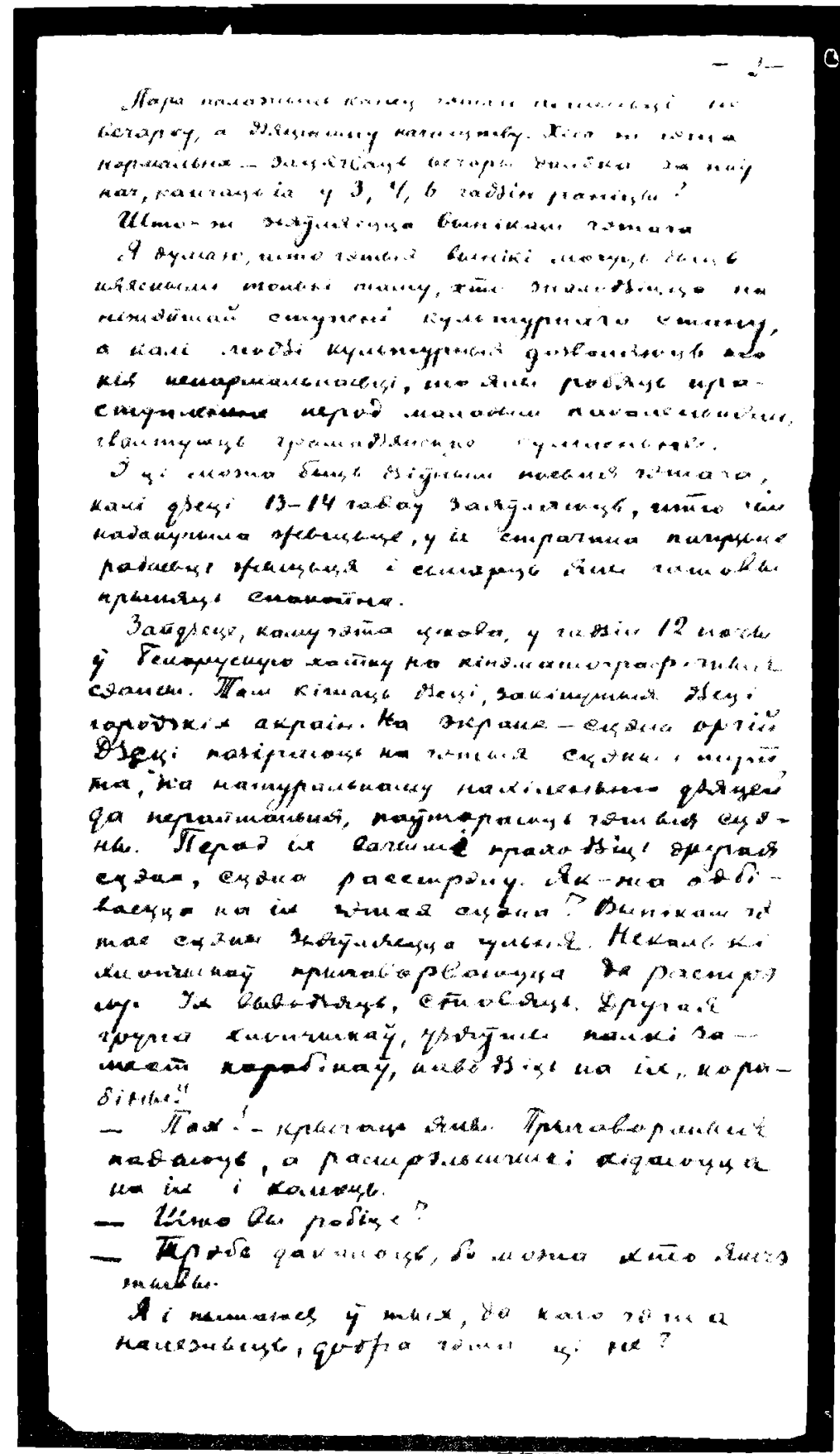

fig. 21. Padumajcie ab dzieciach!, p.2 


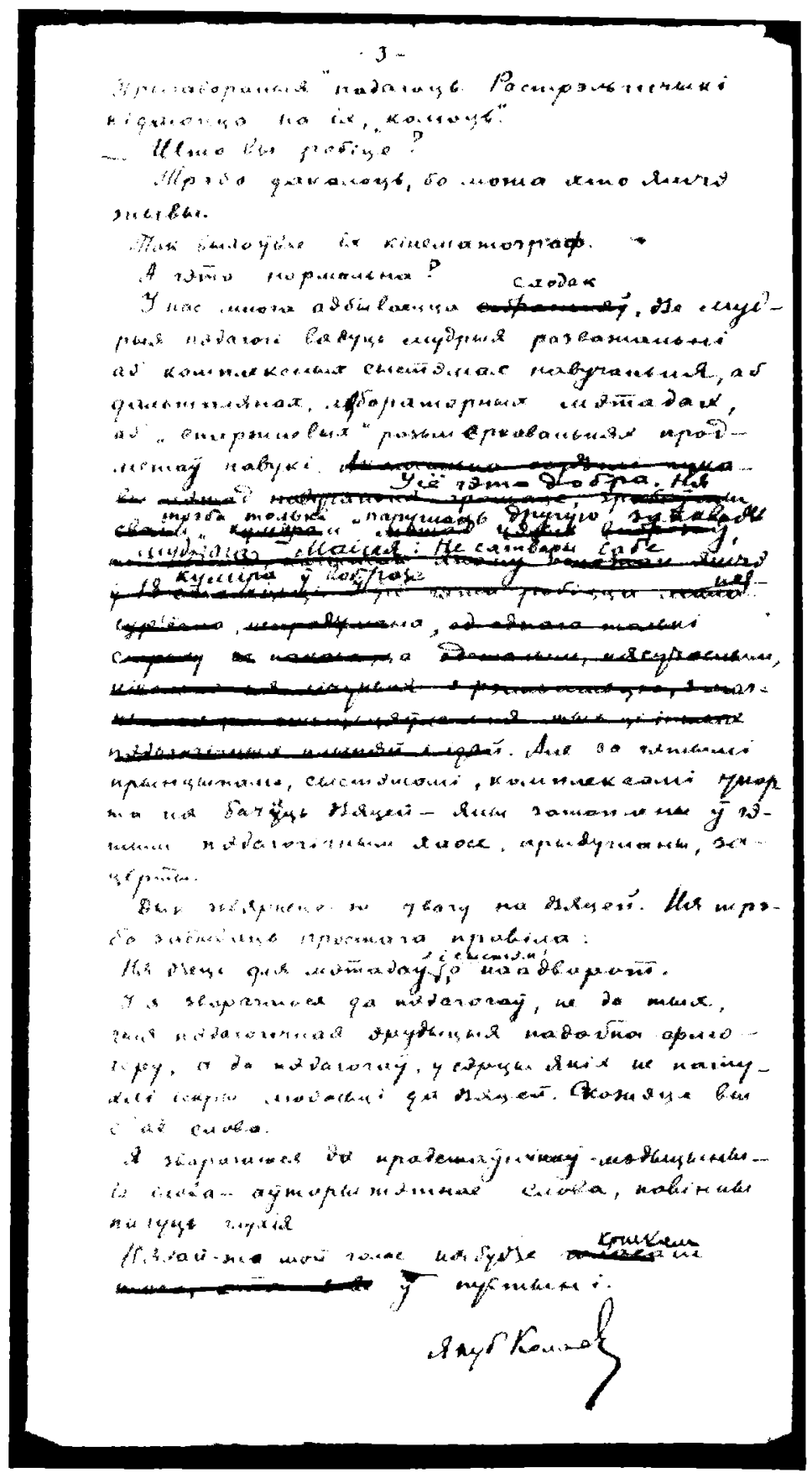

fig. 22. Padumajcie ab dzieciach!, p.3 
Trybs Toonts, Suni:

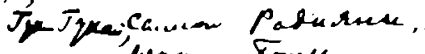

hepe. Srak,

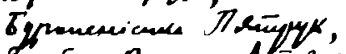

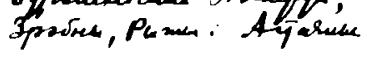

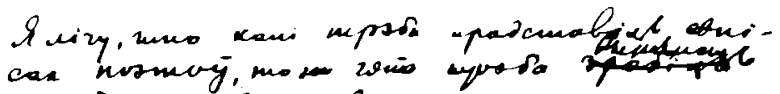

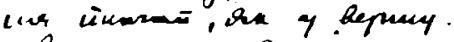

A mox ; zpasars:

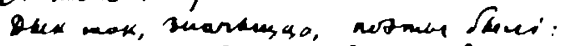

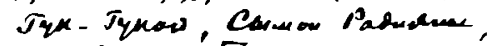
repere "Trye, Syencemsendes Trengyk

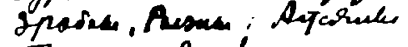
Tor, exhe!

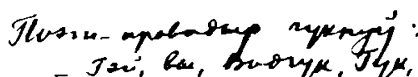

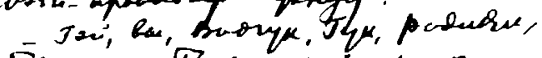

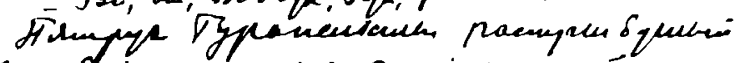

enaporting recese : noses: gaimogy

- Eypaneriner Sy Jean?

- emlumane aofe

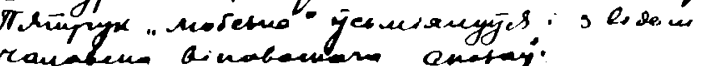

byoy anaray.

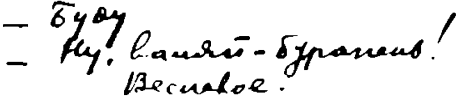

Had myjuam

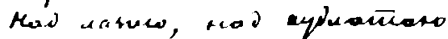

Cins suavimay nolihacasera,

Ad exponmap iwno chañon-

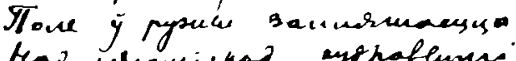

teas uticancinat syspatemens.

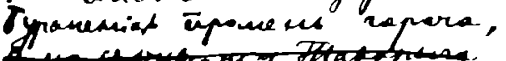

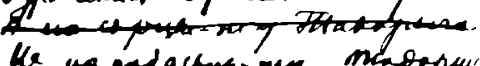

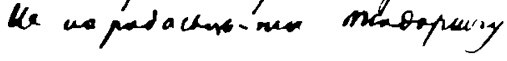

fig. 23. Verso of Padumajcie ab dzieciach!, p.2 


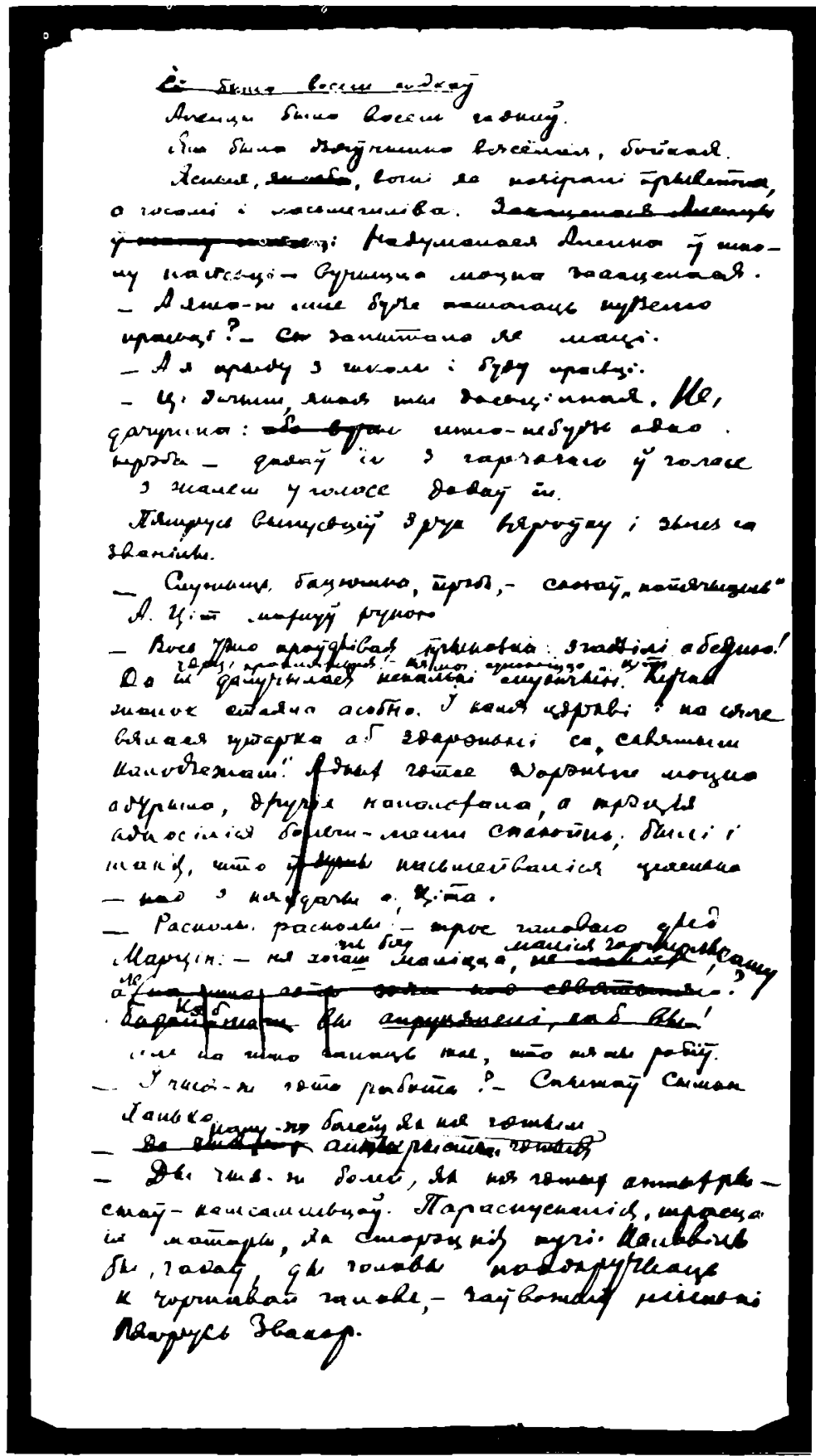

fig. 24. Verso of Padumajcie ab dzieciach!, p.3 


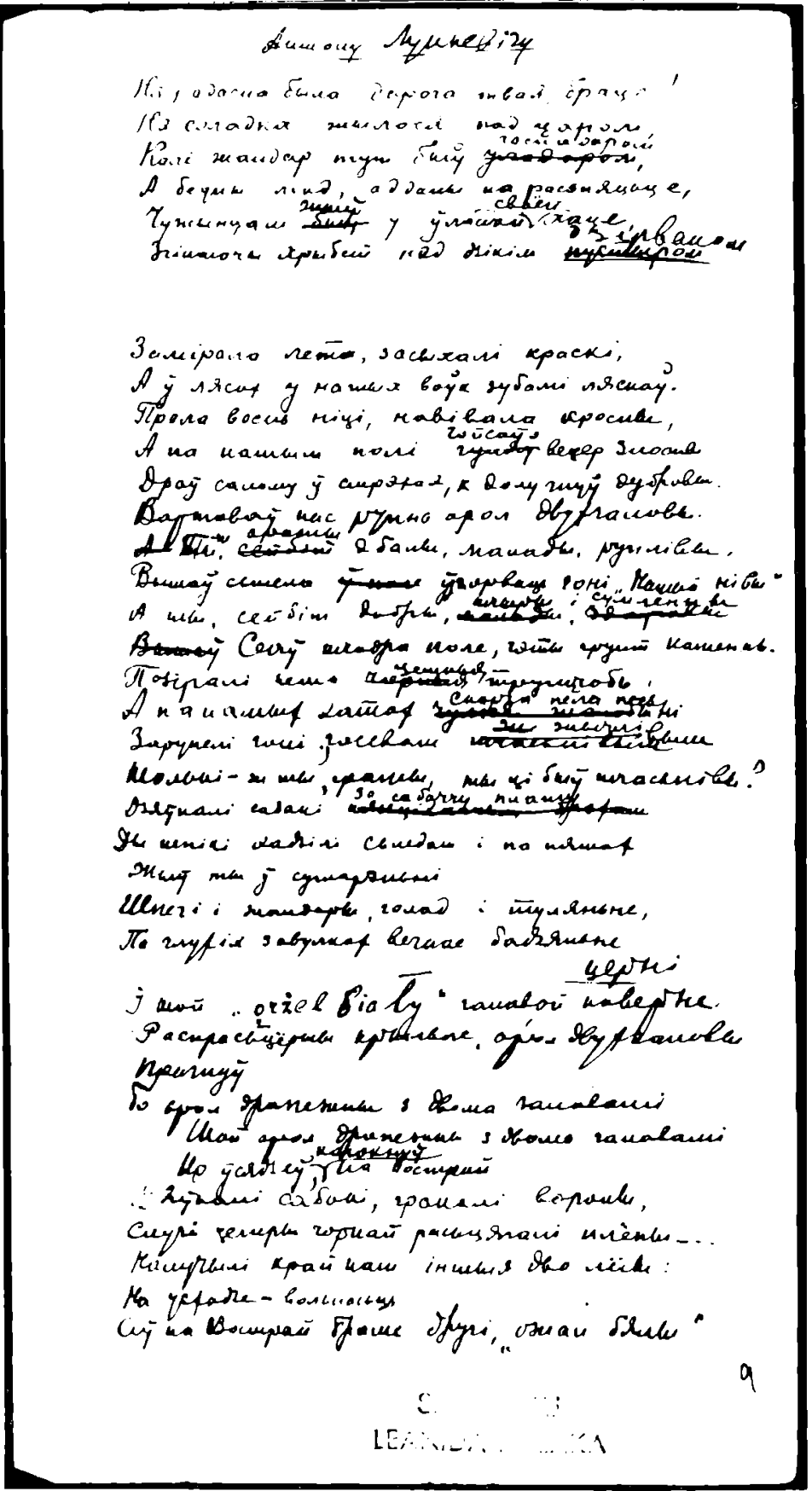

fig. 25. Jakub Kołas, Antonu Łuckieviču 


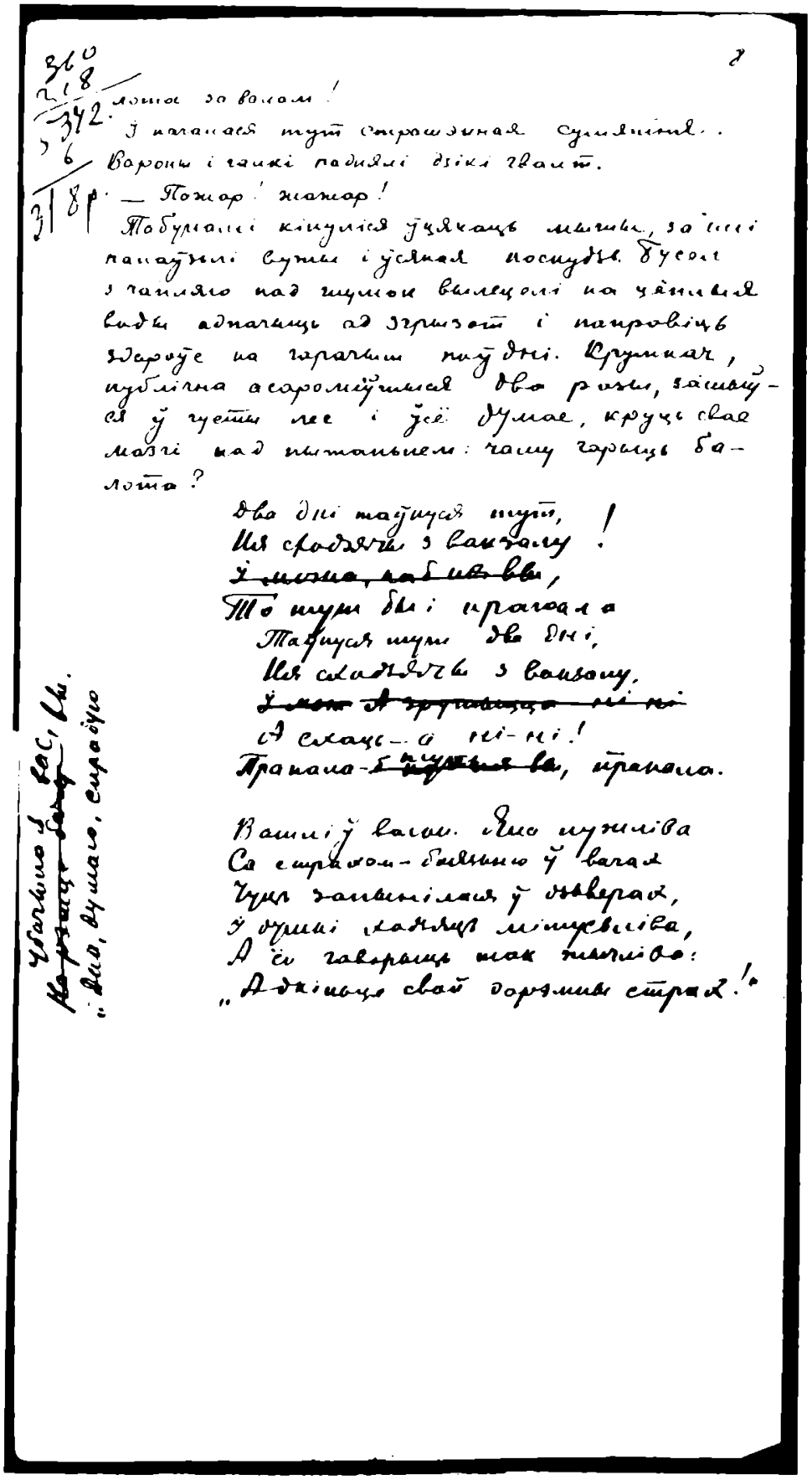

fig. 26. Verso of Antonu Łuckieviču 


\section{THE IMAGES SWARM FREE}

A BI-LINGUAL SELECTION OF POETRY

by

MAKSIM BAHDANOVIČ, ALEŚ HARUN

and

ŹMITROK BLADULA

Translated by Vera Rich

Edited with an Introduction by Arnold McMillin

$£ 3.50$

THE ANGLO-BYELORUSSIAN SOCIETY LONDON 1982 